\title{
An Assessment of the Building Sector Efficiency Resource for the Town of Handlova
}

\author{
October 1995 RECEIVED \\ OCT 041996 \\ OSTI
}

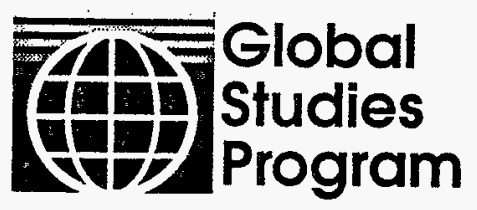

Pacific Northwest Laboratory 


\section{DISCLAIMER}

This report was prepared as an account of work sponsored by an agency of the United States Government. Neither the United States Government nor any agency thereof, nor Battelle Memorial institute, nor any of their employees, makes any warranty, express or implied, or assumes any legal liability or responsibility for the accuracy, completeness, or usefulness of any information, apparatus, product, or process disclosed, or represents that its use would not infringe privately owned rights. Reference herein to any specific commercial product, process, or service by trade name, trademark, manufacturer, or otherwise does not necessarily constitute or imply its endorsement, recommendation, or favoring by the United States Government or any agency thereof, or Battelle Memorial Institute. The views and opinions of authors expressed herein do not necessarily state or reflect those of the United States Government or any agency thereof.

PACIFIC NORTHWEST LABORATORY

operated by

BATTELLE MEMORIAL INSTITUTE

for the

UNITED STATES DEPARTMENT OF ENERGY

under Contract DE-ACO6-76RLO 1830

This document was printed on recycled paper. 


\section{DISCLAIMER}

Portions of this document may be illegible in electronic image products. Images are produced from the best available original document. 
PNL-10847

An Assessment of the Building Sector Efficiency

Resource for the Town of Handlova

October 1995

Prepared for the U.S. Department of Energy under Contract DE-AC06-76RLO 1830

Pacific Northwest Laboratory

Washington, DC 20024 


\section{AN ASSESSMENT OF THE BUILDING SECTOR EFFICIENCY RESOURCE FOR THE TOWN OF HANDLOVA}

\section{FEBRUARY 1994}

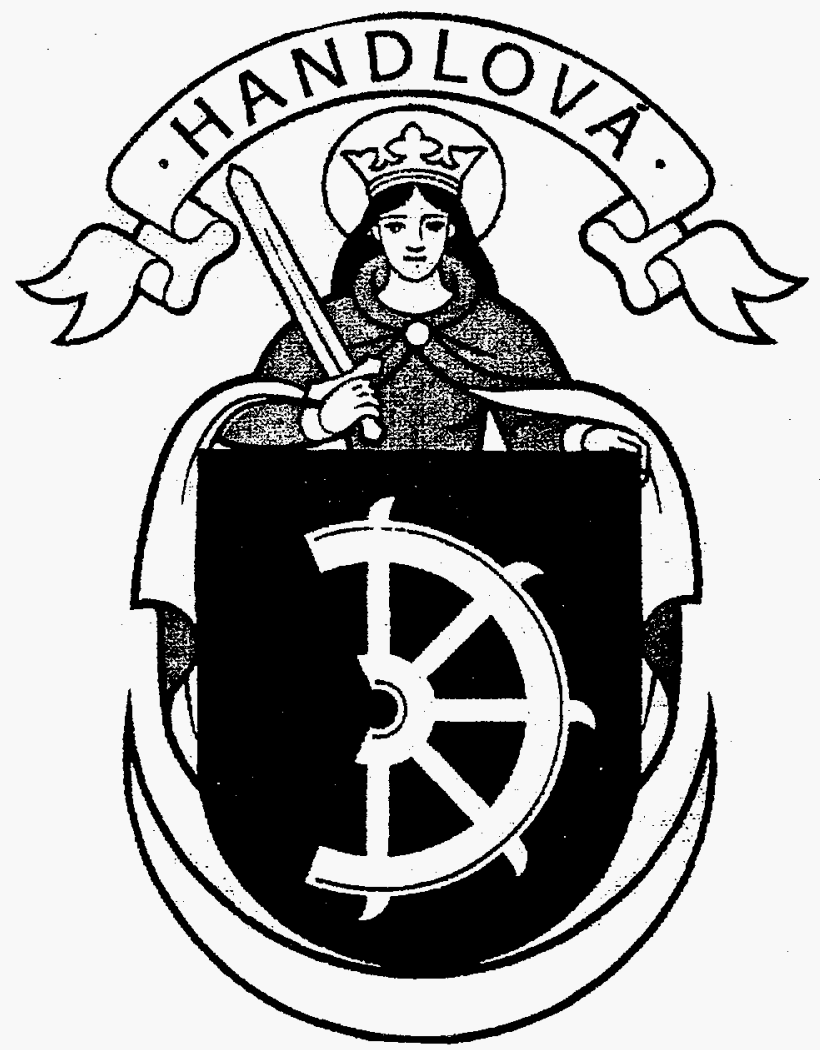

Prepared by:

Tecogen Division

Thermo Power Corporation

Under Contract With:

Battelle, Pacific Northwest Laboratory

Assisted by:

EGU Bratislava 


\section{TABLE OF CONTENTS}

SUMMARY

1. INTRODUCTION

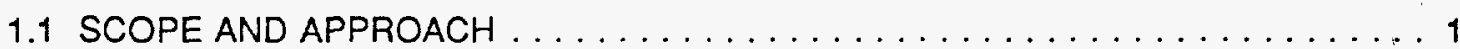

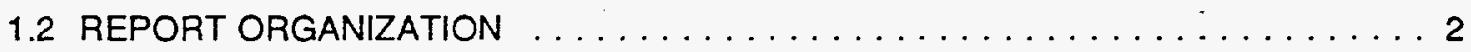

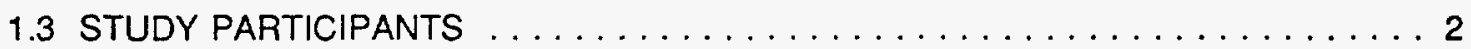

2. ENERGY USE BASELINE AND DEMAND FORECAST $\ldots \ldots \ldots \ldots \ldots \ldots \ldots$

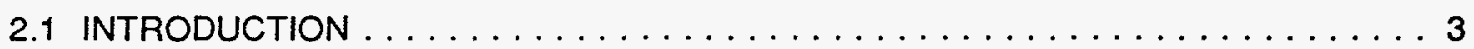

2.2 DEFINITION OF DEMAND SIDE SECTORS $\ldots \ldots \ldots \ldots \ldots \ldots \ldots \ldots \ldots$

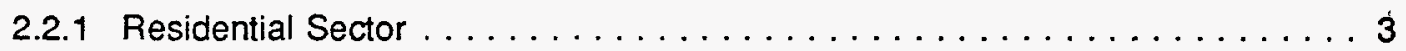

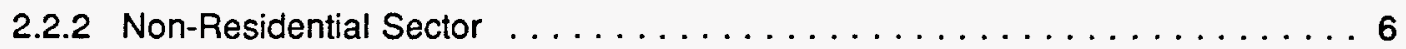

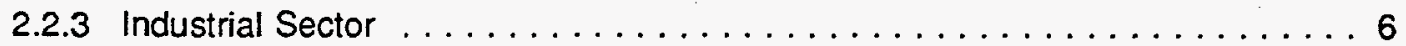

2.3 DEMAND SIDE BASELINE $\ldots \ldots \ldots \ldots \ldots \ldots \ldots \ldots \ldots \ldots \ldots \ldots$

2.3.1 Energy Consumption by Sectors . . . . . . . . . . . . . . 12

2.3.1.1 Residential Sector Energy Consumption . . . . . . . . . 12

2.3.1.2 Non-Residential Sector Energy Consumption . . . . . . . . . . . . 14

2.3.1.3 Industrial Sector Energy Consumption . . . . . . . . . . . . 14

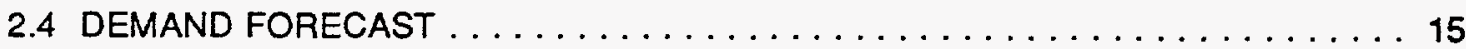

3. BUILDING SECTOR EFFICIENCY ASSESSMENT $\ldots \ldots \ldots \ldots \ldots \ldots \ldots \ldots$

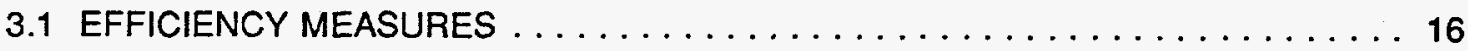

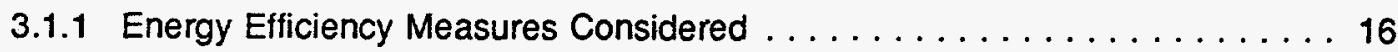

3.1.1.1 Building Envelope Measures $\ldots \ldots \ldots \ldots \ldots \ldots \ldots$

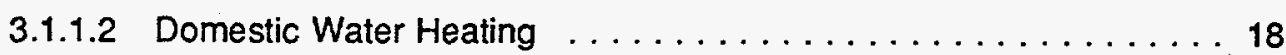

3.1.1.3 Heating System . . . . . . . . . . . . . . . . 19

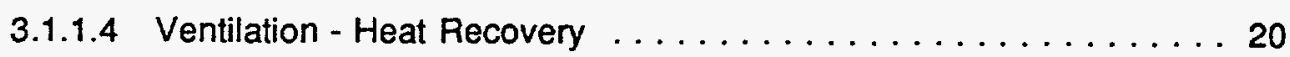

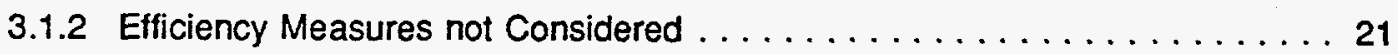

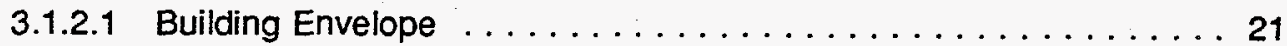

3.1.2.2 Domestic Water Heating ................... 22

3.1.2.3 Heating System . . . . . . . . . . . . . . . . 22

3.1.2.4 Ventilation - Heat Recovery ................... 23

3.1.3 Summary of Efficiency Measures Considered ............. 23 
TABLE OF CONTENTS (Continued)

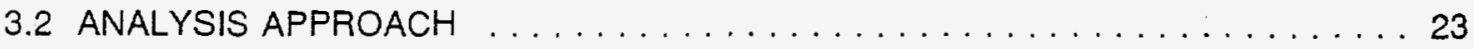

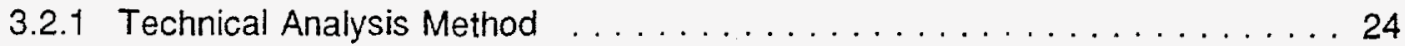

3.2.1.1 Analyses of Building Envelope Measures . . . . . . . . . . 24

3.2.1.2 Analyses of Water Heating Measures . . . . . . . . . . . 26

3.2.1.3 Analyses of Building Heating System . . . . . . . . . . 27

3.2.1.4 Analyses of Ventilation and Heat Recovery Measures . . . . . . 27

3.2 .2 Economic Analysis . . . . . . . . . . . . . . . . . . . . . . . . . 27

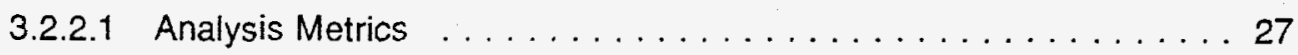

3.3 BUILDING SECTOR EFFICIENCY ASSESSMENT RESULTS . . . . . . . . . . 30

3.3.1 Baseline Efficiency Assessment . . . . . . . . . . . . . . 31

3.3.1.1 Residential Sector Baseline Efficiency . . . . . . . . . . . . 31

3.3.1.2 Non-Residential Sector Baseline Efficiency . . . . . . . . . . 33

3.3.2 Sensitivity Analysis . . . . . . . . . . . . . . . . . . 34

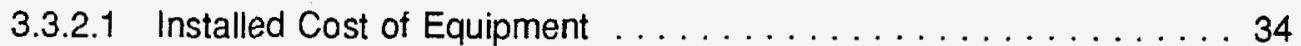

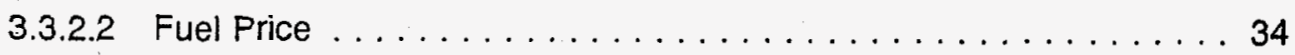

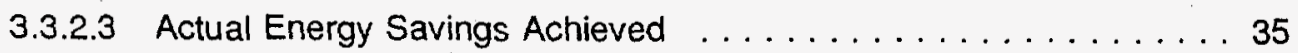

3.3.2.4 Summary of Sensitivity Analysis $\ldots \ldots \ldots \ldots \ldots \ldots \ldots \ldots$ 


\section{LIST OF TABLES}

2.1 Residential Building Stock Data (Town of Handlova) $\ldots \ldots \ldots \ldots \ldots \ldots$

2.2 Heating Plant/User Energy Consumption Metering Comparison $\ldots \ldots \ldots \ldots$

2.3 Total Primary Fuel Input for the Production of Heat Energy, $1992 \ldots \ldots \ldots \ldots \ldots$

2.4 Primary Heat Energy Utilization, $1992 \ldots \ldots \ldots \ldots \ldots \ldots \ldots \ldots \ldots \ldots \ldots$

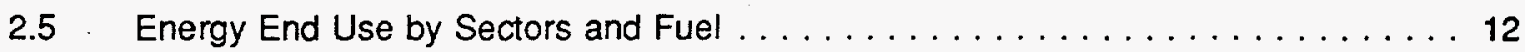

2.6 Residential Sector Space Heating Energy Consumption by Building Type

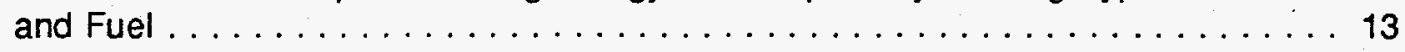

2.7 Residential Sector Water Heating Energy Consumption by Building Type

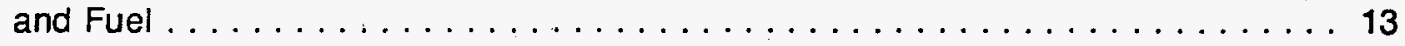

2.8 Non-Residential Space and Water Heating Energy Consumption by Building Type and Fuel . ......................... 14

2.9 Industrial User Energy Consumption $\ldots \ldots \ldots \ldots \ldots \ldots \ldots \ldots \ldots \ldots$

3.1 Efficiency Measures Considered and Estimated Per Unit Cost and Lifetime ... . . . 25

3.2 Base Economic Assumptions for Analysis of Efficiency Measures . . . . . . . . 29

3.3 Fuel Price Levels Used to Drive Analysis of Efficiency Resource and Sensitivity

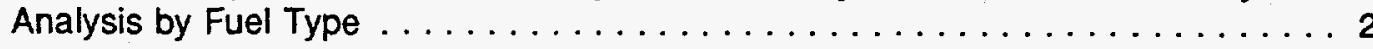

3.4 Residential Sector Cost-Effective Space and Water Heat Efficiency Resource by Building, Fuel and Equipment Type Using Base Assumptions and 1993

Fuel Prices . . . . . . . . . . . . . . . . . . . . . . . 32

3.5 Economic Analysis Results of Residential Sector Cost-Effective Energy Efficiency Resource for 1993 Baseline ... . . . . . . . . . . . . 33

3.6 Estimated Non-Residential Space and Water Heat Efficiency Potential by Fuel and Heating System Type, $1993 \ldots \ldots \ldots \ldots \ldots \ldots \ldots$. . . . . . . . . .

3.7 Sensitivity of the Energy Saving Potential and the Cost of Delivered Heat to Fuel Prices . . . . . . . . . . . . . . . . . . . . . . 35

3.8 Sensitivity of the Energy Saving Potential and the Cost of Delivered Heat to Actual Energy Savings Achieved 


\section{LIST OF FIGURES}

$2.1 \quad$ Apartment Buildings (1951-52), Group $1 \ldots \ldots \ldots \ldots \ldots \ldots \ldots \ldots \ldots$

$2.2 \quad$ Apartment Buildings (1954-57), Group $2 \ldots \ldots \ldots \ldots \ldots \ldots \ldots$

2.3 Prefab Buildings Type T06 B (1968-84), Group $3 \ldots \ldots \ldots \ldots \ldots$

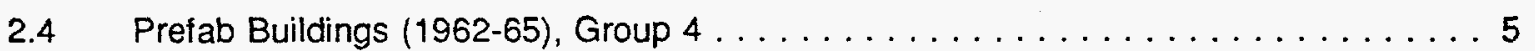

2.5 Prefab Buildings $(1987-91)$, Group $5 \ldots \ldots \ldots \ldots \ldots \ldots \ldots \ldots \ldots \ldots \ldots \ldots \ldots \ldots$

2.6 Single and Two Family Detached Houses, Group 6 and $7 \ldots \ldots \ldots$

2.7 District Heat Energy Flow $\ldots \ldots \ldots \ldots \ldots \ldots \ldots \ldots \ldots \ldots \ldots \ldots \ldots \ldots \ldots$ 


\section{ACKNOWLEDGEMENTS}

Mr. Andrew Popelka, Program Manager, would like to give special recognition to the following people who greatly contributed to the efforts of this project.

Gratitude is expressed to Len Rogers, U.S. Agency for International Development (AID), Marian Krsko, AID Slovak Mission, and Elaine Guthrie, U.S. Department of Energy, for making this study possible. Special thanks to Peter Sestak at EGU Bratislava for leading the Slovak effort, and Ed Doyle at Tecogen for his technical support and oversight. Recognition to Bill Chandler, Director of PNL's Advanced International Studies Unit, and Tom Secrest, Program Manager at PNL for their guidance in this effort. Special appreciation to Kim Myles for the final preparation of this report. 


\section{SUMMARY}

The Town of Handlova in the Slovak Republic is considering options for providing energy services to its citizens in order to lower their energy bills and reduce pollution created by the burning of low quality brown coal. The U.S. Agency for International Development (AID), under the Support for Eastern European Democracy (SEED) Program, agreed to fund an assessment of the space and water heat efficiency potential in the building sector in the Town of Handlova. The assessment was funded through the U.S. Department of Energy's (DOE) Office of Energy Efficiency and Renewable Energy (EE) and conducted by the Pacific Northwest Laboratories (PNL) and its subcontractors, Tecogen, a U.S. based energy research and development firm, and EGU, a Slovak Energy Research Institute.

The purpose of this assessment is to develop information on the building sector energy efficiency and improvement potential for use by the Town management to support decisions on the provision of energy services to Handlova citizens. In support of this purpose, specific objectives of this effort are:

- to characterize baseline space and water heat energy use and efficiency improvement potential that exists in the residential and non-residential building sectors in the municipality of Handlova.

- to develop capability in Slovak organizations to conduct energy assessments modeled after procedures employed in the U.S. to support energy efficiency resource acquisitions.

This effort is not intended to provide a definitive analysis to enable selection of specific technologies for application, but rather to identify the major areas of efficiency improvement potential and cost-effectiveness.

The current changes in Slovakia toward a market economy are causing prices of fuels and energy to be in a state of flux. In order to analyze the impact of fuel and energy price changes on energy saving potential, four levels of prices were established. Level 1 represents current, subsidized and controlled prices of energy; Level 2 assumes removal of state subsidies; Level 3 represents a moderate increase, the most likely scenario of price development; and, finally, Level 4 represents a substantial fuel and energy price increase.

Subject to the data limitations and assumptions made, a significant efficiency resource exists in the space and water heating end-uses in the residential and non-residential building sectors. At the fuel price level at which the energy savings potential was evaluated, this resource amounts to $42 \%$ of the total building sector space and water heat energy consumption. At the current fuel price, Level 1 and Level 2, the savings potential represents $35 \%$ and $40 \%$, respectively, of building sector consumption. 
About $89 \%$ of the efficiency resource resides in the district heating area at current fuel prices; this is slightly lower for higher fuel prices. Space and hot water heat provided by gaseous fuels is the next largest resource, ranging from $9 \%$ to $17 \%$ of the total water heating load. The onsite coal consumption accounts for less than $1 \%$ of the total efficiency resource under the lowest fuel price scenario. Under the highest price scenario, the coal based efficiency resource increases to about $7 \%$ of the total resource. The electricity based efficiency resource is the least sensitive to fuel prices and amounts to less than $0.1 \%$ of the total efficiency resource in all price scenarios.

Nearly $80 \%$ of the residential sector efficiency resource is in the high rise multi-family building types, and of this, $97 \%$ is in the district heating area for all fuel price levels. In the nonresidential sector, about $65 \%$ of the efficiency potential resides in the education and health facilities under all four fuel price scenarios. The share of the efficiency potential in the education and health (hospital) building types accounted for by the district heat area is about $81 \%$.

The levelized energy cost of the total efficiency resource is on the order of $132 \mathrm{Sk} / \mathrm{GJ}$ as compared to the Level 1 current consumption weighted average energy price of $139 \mathrm{Sk} / \mathrm{GJ}$. At Level 3 (realistic increase), which was analyzed in this report, the levelized energy cost of 135 Sk/GJ compares to the consumption weighted prices of $232.5 \mathrm{Sk} / \mathrm{GJ}$. Under current prices, the levelized energy cost of the efficiency resource within the district system fuel type is on the order of $135 \mathrm{Sk} / \mathrm{GJ}$ as compared to $165 \mathrm{Sk} / \mathrm{GJ}$ for district heat. Under the assumed Level 3 price scenario, district heat is projected to increase to $270 \mathrm{SK} / \mathrm{GJ}$ as compared to a levelized energy cost for the district heat based efficiency resource of $144 \mathrm{Sk} / \mathrm{GJ}$.

Under three future consumption variants and in the absence of actions to acquire energy efficiency, the building sector space and water heat energy consumption is projected to be stable in the first variant, increase by $5.22 \%$ in the second variant, and increase by $11.22 \%$ in the third variant by the year 2022. Dependent upon changes in fuel prices, the future building sector space and water heat energy consumption could decrease on the order of $35 \%$ to $44 \%$ if the entire resource were acquired.

With respect to the second major objective, the Slovak team led by EGU Bratislava participated in all aspects of the study with the U.S. participants serving primarily in an advisory capacity, It is felt that the assessment process was successfully transferred to the Slovak study participants, and the process and results were well received by the Town staff. 


\section{INTRODUCTION}

The Town of Handlova in the Slovak Republic is considering options for providing energy services to its citizens. The existing Central Heating Plant is on the end of its useful life and must be replaced. The Town is evaluating alternative solutions of providing its citizens with thermal energy at lowest possible cost and at the lowest pollution by the energy sources. In the Summer of 1993, the U.S. Agency for International Development (AID) under the Support for Eastern European Democracy (SEED) Program, agreed to fund an assessment of the options for providing heating energy to the buildings sector in the Town of Handlova.

This report documents the assessment of the buildings sector efficiency resource conducted by the Pacific Northwest Laboratories (PNL) and its subcontractors, Tecogen, a U.S. based energy research and development firm, and EGU Bratislava, the Slovak Power Research Institute.

\subsection{SCOPE AND APPROACH}

The purpose of this assessment is to develop information on the building sector energy efficiency potential needed by the Town management to support decisions on the provision of energy services to the citizens of Handlova. In support of this purpose, specific objectives of this effort are:

- To characterize baseline space and water heat energy use and efficiency potential that exists in the residential and non-residential building sectors in the municipality of Handlova.

- To develop capability in Slovak organizations to conduct energy assessments modelled after procedures employed in the U.S. to support energy resource acquisitions.

This effort is not intended to provide a definitive analysis to enable selection of specific technologies for application.

The baseline energy use characterization segments the residential and non-residential building stock into individual building types and estimates the space and water heat energy consumption by each building type, fuel type and equipment type. The efficiency potential is then estimated for each building, fuel and equipment type based upon cost-effectiveness criteria.

A key aspect of the effort is to build the capability in Slovak organizations/individuals for conducting subsequent assessments employing integrated resource planning principles used by the U.S. utility industry. To this end, Slovak organizations and experts participated in all aspects of the study with the U.S. participants serving primarily in an advisory capacity. 


\subsection{REPORT ORGANIZATION}

This report summarizes the detailed assessment that was written in Slovak and is organized into the following two main chapters:

- Chapter two provides the baseline and forecast of the demand for thermal energy consumed to provide space and water heat;

- Chapter three presents the efficiency resource options considered and the estimated efficiency resource;

For readers interested in converting the energy and currency units to British Thermal Units (BTUs) and dollars, one gigajoule (GJ) equals one million BTU and about 32 Slovak Koruna (SK) equals one US dollar. This report is also published in Slovak language.

\subsection{STUDY PARTICIPANTS}

PNL, one of DOE's five multi-program research laboratories, conducts a significant number of programs in the area of energy efficiency and integrated resource planning. PNL's Advanced International Studies Unit (AISU) conducts research on global climate change and manages cooperative programs to transfer energy-efficiency practices and technologies to other countries. PNL provided the technical and management oversight for this effort.

PNL/AISU contracted with the U.S. firm Tecogen and the EGU - Energy Research Institute in Bratislava to support the integrated assessment activities. Tecogen, a division of Thermo Power Corporation, a Thermo Electron company, specializes in the development and manufacturing of gas-fired cogeneration and cooling equipment and has significant experience in energy demand assessment and field evaluation of energy producing and consuming systems. Tecogen conducted the assessment of the demand-side resource opportunities and provided technical support for the integration of the demand and supply resources.

EGU is currently a government organization (soon to be privatized). EGU provided the Slovak lead for the demand-side and supply-side assessment activities and the interface to the Town of Handlova for project communications, and represented the study recommendations to the Town and other organizations. EGU acquired the expertise of Mr. Certik and other local experts to assist with the collection of energy consumption data and the building of stock characterization. 


\section{ENERGY USE BASELINE AND DEMAND FORECAST}

\subsection{INTRODUCTION}

This chapter presents the baseline thermal energy use data and future energy demand forecast scenarios that were used to project the future demand for the town of Handlova. Section 2:2 defines the breakdown of the thermal energy consumption sectors used in the study and provides additional information on the sectors that was needed for the energy efficiency assessments. In Section 2.3, the baseline thermal energy use for the entire town is provided by fuel form, sector and major end-use categories (space heating and water heating). The population and industrial growth scenarios used to forecast future energy demand through the Year 2022 is presented in Section 2.4 .

\subsection{DEFINITION OF DEMAND SIDE SECTORS}

For the purpose of this study, the town was divided into three energy consumption sectors: residential, non-residential and industrial. These sectors were then further subdivided and the specific parameters needed to support the energy efficiency analyses were identified. The study concentrated on the residential sector since this is the largest thermal energy consumer.

\subsubsection{Residential Sector}

The data on residential building stock were acquired from the databank maintained by the Building Management Company in Handlova (Bytovy podnik Mesta Handlova), from the Administration Office of the Town Hall and from AGS Atelier Company which was involved in town development studies. The residential sector was then divided into the following seven representative residential building types:

Res-1 Apartment Buildings 2 to 3 floors (1951-1952)

Res-2 Apartment Buildings 3 to 7 Floors (1954-1957)

Res-3 Pre-fab Buildings T 06 B (1968-1984)

Res-4 Pre-fab Buildings (1962-1965)

Res-5 Pre-fab Buildings P1-15-NKS (1982-1991)

Res-6 Two family detached houses

Res-7 Single family detached houses

For building types Res-1 through Res-5, the years in which these buildings were constructed is provided in brackets. Figures 2.1 through 2.6 show typical buildings representing each residential building type group. The total number of residential buildings and apartment units along with the total heated square meters in each building type are shown in Table 2.1 . 


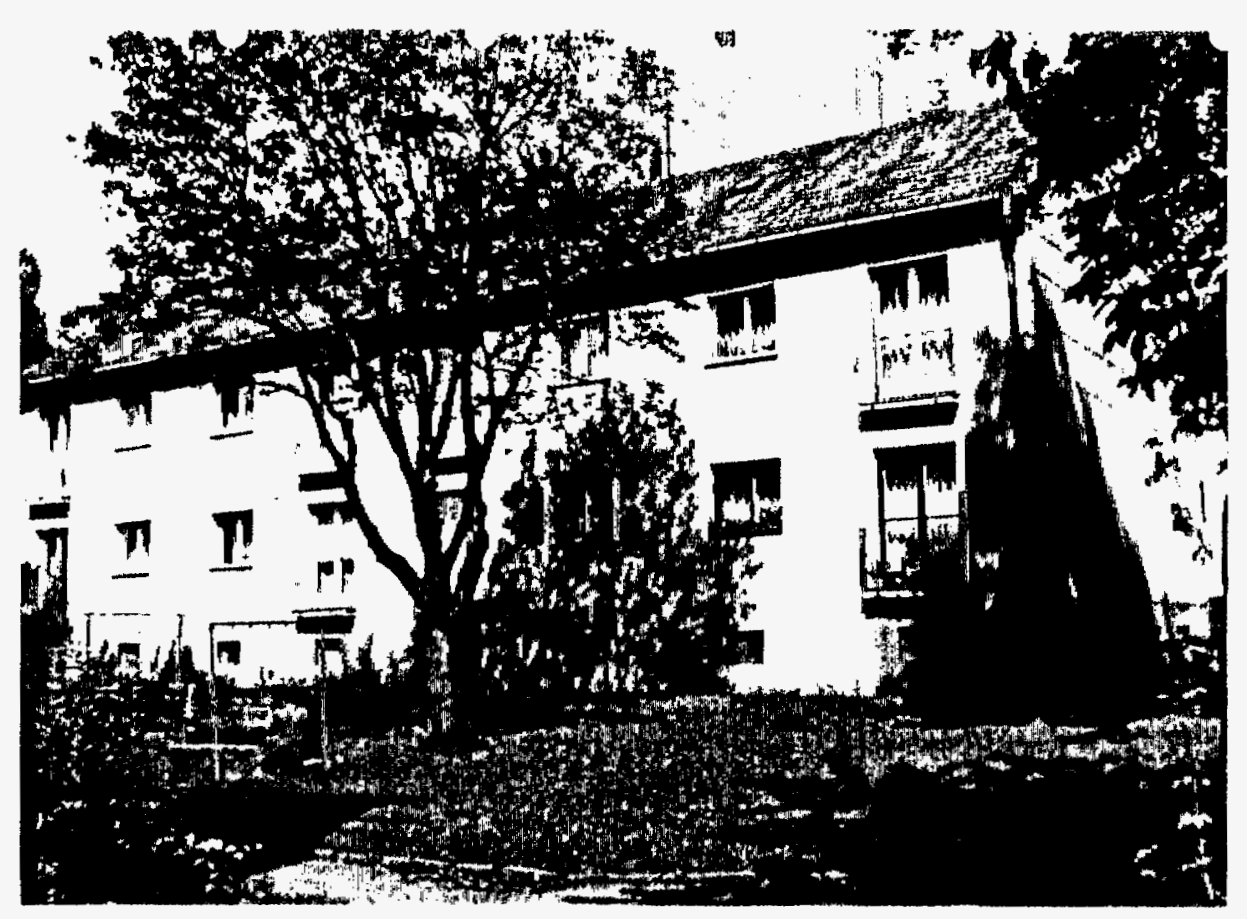

Figure 2.1 - Apartment Bulldings (1951-52), Group 1

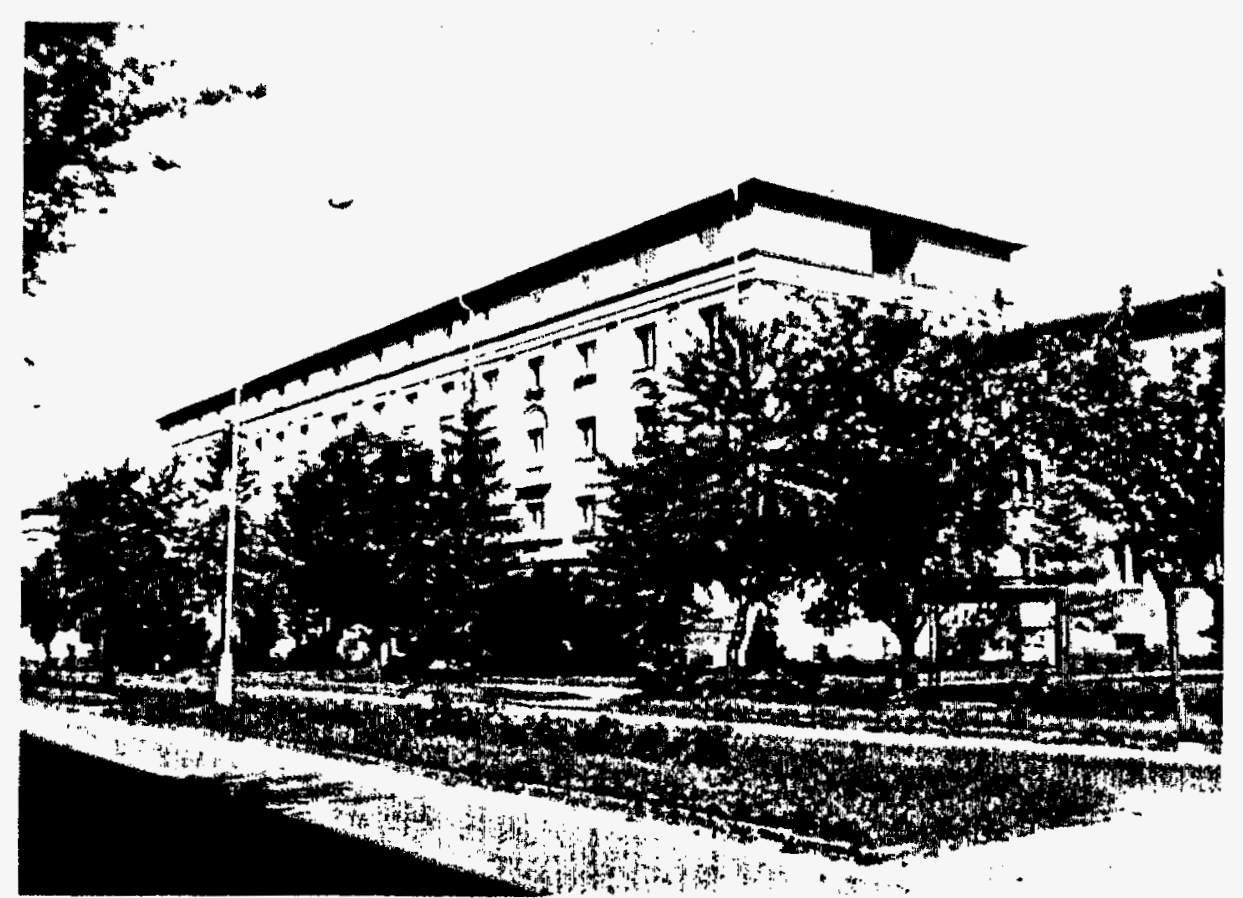

Figure 2.2 - Apartment Buildings (1954-57), Group 2

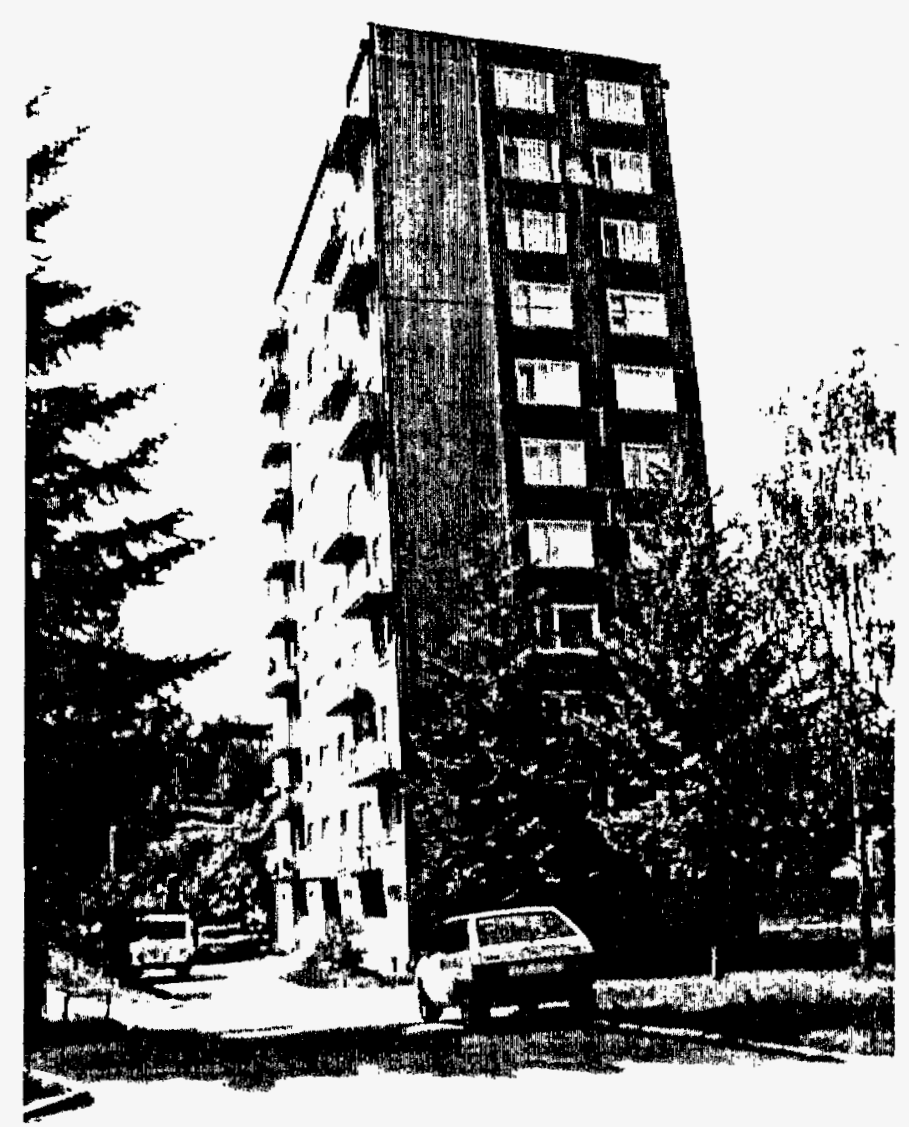

Figure 2.3 - Prefab Bullaings Type TO6 B (1968-84), Group 3 


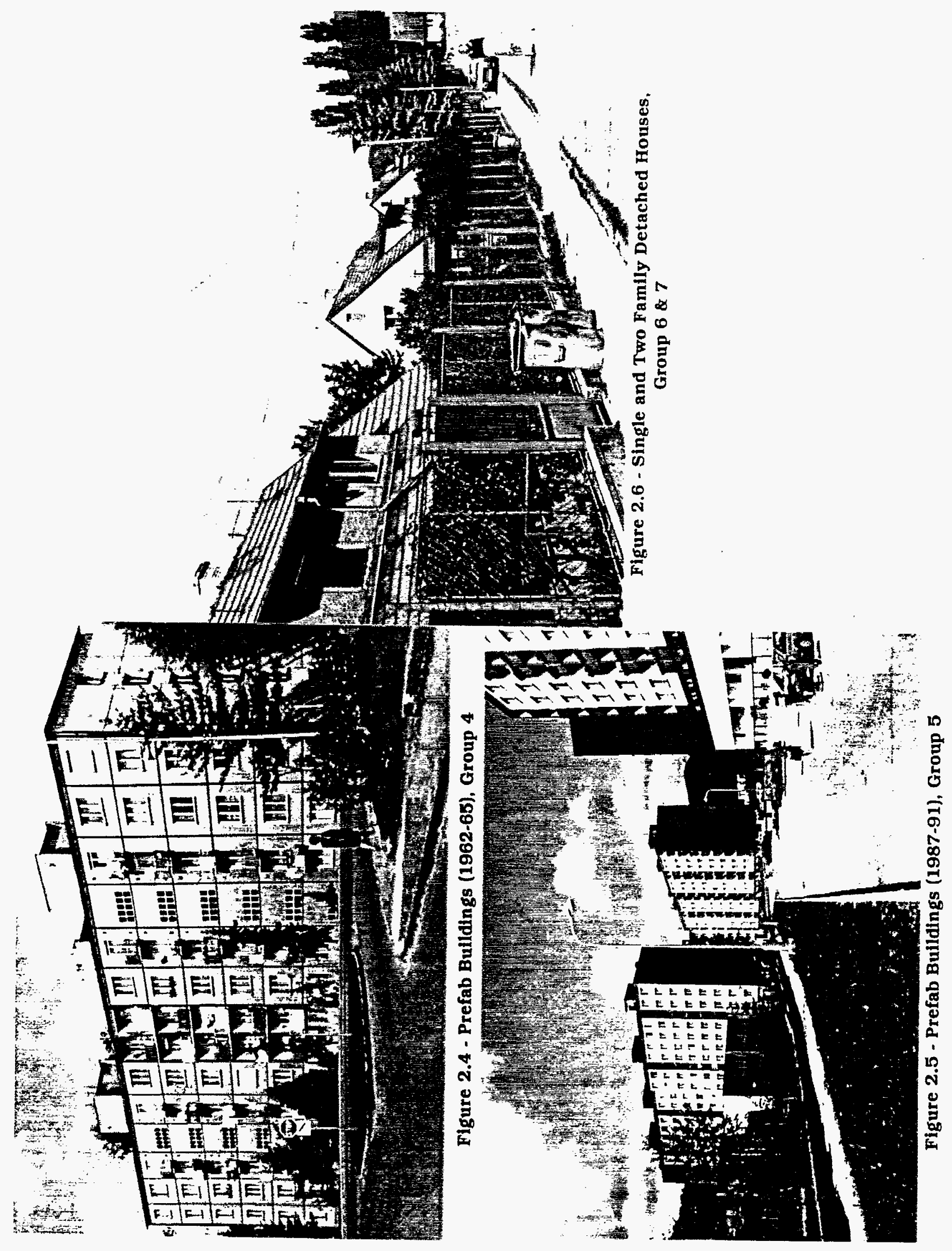


The data in Table 2.1 for apartment building types Res-1 through Res- 5 were acquired from the available building layout drawings and from the billing files of the Bytovy Podnik Mesta Handlova (BPMH). The heated floor space data included only space with heating elements (radiators) installed in the room. The difference between this heated floor space and the total floor space actually heated (maintained at room temperature) was estimated based on actual layout drawings. The heated space for building types Res- 6 and Res-7 was estimated based on typical single and two family house designs found in Handlova and was compared to information maintained by the Administration Office of the Town of Handlova.

The data indicate that approximately $27 \%$ of residential heated floor space is in brick-built apartment buildings from the 1950's (Res 1-2), 49\% in the pre-fab multi-family housing (Res 3-5), and the remaining $24 \%$ in detached single and two family houses.

\subsubsection{Non-Residential Sector}

The seven building types identified in the non-residential sector are as follows:

$\begin{array}{ll}\text { NonRes-1 } & \text { Education (primary schools, dormitory) } \\ \text { NonRes-2 } & \text { Culture } \\ \text { NonRes-3 } & \text { Health Facilities (including nursery schools) } \\ \text { NonRes-4 } & \text { Sport facilities } \\ \text { NonRes-5 } & \text { Office/Administration } \\ \text { NonRes-6 } & \text { Services and Retail } \\ \text { NonRes-7 } & \text { Accommodation, Hotels }\end{array}$

Data limitations coupled with time and budget limitations did not permit a comparable characterization of the non-residential building stock. In addition to that, each of the non-residential building types alone represent a very small fraction of the total energy consumption (maximum $3.5 \%$ ) and all types of buildings in this sector combined represent less than $20 \%$ of the total energy consumption.

\subsubsection{Industrial Sector}

The industrial sector in Handlova is represented by the following firms: Coal Mine Handlova including garages, Slovenka, Lahke Universaine Konstrukcie, AMK, Chemika, CSD station and State Agricultural Farm. The thermal energy is used only for space and water heating. Technological use of thermal energy is negligible. Except for the Coal Mine Industry, this energy demand sector is relatively small and was not characterized in detail because of the time and budget limitations of the project. 
Table 2.1 - Reșidential Building Stock Data Town of Handlova

\begin{tabular}{|c|c|c|c|c|c|c|c|c|c|c|c|c|c|c|c|c|}
\hline \multirow[t]{2}{*}{ 610010 } & \multicolumn{4}{|c|}{ Number of bidogs } & \multirow[t]{2}{*}{ rolot } & \multicolumn{4}{|c|}{ Number of cpartments } & \multirow[t]{2}{*}{ Apart } & \multicolumn{4}{|c|}{ Heated Area } & \multirow{2}{*}{$\begin{array}{l}\text { Seated } \\
\text { rootal } \\
\text { rn' }\end{array}$} & \multirow{2}{*}{ Heated } \\
\hline & olst & coal & Gas & 81001 & & Ooistr & eoal & Gas & Elect & & olstr. & col & Gas & $\mathrm{Ellod}$ & & \\
\hline 1 & 0 & 0 & 22 & 0 & 22 & 0 & 0 & 232 & 0 & 232 & 0 & 0 & 12517 & 0 & 12517 & 3.71 \\
\hline 2 & 40 & 1 & 6 & 0 & 47 & 1198 & 12 & 114 & 0 & 1324 & 70471 & 632 & 7943 & 0 & 79046 & 23.46 \\
\hline 3 & 29 & 0 & 0 & 0 & 29 & 1567 & 0 & 0 & 0 & 1567 & 89719 & 0 & 0 & 0 & 89719 & 26.62 \\
\hline . 4 & 10 & 0 & 0 & 0 & 10 & 376 & 0 & 0 & 0 & 376 & 20639 & 0 & 0 & 0 & 20639 & 6.12 \\
\hline 5 & 16 & 0 & 0 & 0 & 16 & 868 & 0 & 0 & 0 & 868 & 54947 & 0 & 0 & 0 & 54947 & 16.31 \\
\hline 6 & 0 & 5 & 128 & 0 & 133 & 0 & 10 & 256 & 0 & 266 & 0 & 694 & 18412 & 0 & 19106 & 5.67 \\
\hline 7 & 0 & 256 & 284 & 20 & 560 & 0 & 256 & 284 & 20 & 560 & 0 & 24421 & 34069 & 2511 & 61001 & 18.10 \\
\hline $10 \mathrm{OA}$ & 95 & 262 & 440 & 20 & 817 & 4009 & 278 & 286 & 20 & 5193 & 23.576 & 2574 & 72941 & 2501 & 336975 & 100 \\
\hline
\end{tabular}




\subsection{DEMAND SIDE BASELINE}

This section provides information on thermal energy consumption in the Town of Handlova in 1992. Consumption is provided by major fuel form and by the defined sectors. For the purpose of this study, the energy consumption data can be deemed to be reasonably accurate. In some instances, such as coal consumption in residential homes, the estimation had to be supported by calculations. Consumption data for each fuel type were developed as follows:

Solid fuel consumption for other than Heating Plant use was estimated based on limited data on deliveries from the coal distribution company (Uholne Sklady) and from coal mine information on employee free coal deliveries. Calculations were used to suppont the assumptions made. The coal consumption and the coal quality data (heating value) for the Heating Plant fuel were obtained from the Heating Plant accounting files.

Natural gas consumption data were obtained from the billing records of the local gas utility (Slovensky Plynarensky Podnik Prievidza). These records are well maintained and provided good quality data.

Electrical consumption data is available from metered consumption records for individual customers. Each living unit is metered separately. This data includes several end-uses (space heating, hot water, appliances, etc.). An estimate was made of the percentage used for space heating and water heating.

District heat energy consumption was developed from data provided by the Heating Plant. Energy delivery metering is performed for billing purposes by the Heating Plant on the primary side of the Heat Exchanger Stations. Steam flow and temperature is measured, return condensate is assumed at $40 \mathrm{deg} C$ and the condensate mass flow is assumed the same as steam flow. Such measurement does not provide accurate energy consumption data. A simultaneous metering of energy consumption by recently user-installed metering on residential buildings had shown up to a $18 \%$ difference between the heating plant and the end-user measurements. Losses in secondary distribution, accuracy of measurement and assumed fixed condensate temperature are to blame for the differences. A comparison of both measurements for the first three months (1/1/93 through 31/3/93) is shown in Table 2.2. This indicates that there may be some inaccuracy in the energy consumption data used. However, it is beyond the scope of this study to resolve this problem. The Heating Plant data were used in this study. 
The fuel input to produce the thermal energy required by the town is summarized by the location of conversion and by the type of fuel in Table 2.3. On-site consumption refers to the conversion of fuel to heat and/or hot water within the individual living space, e.g. single family dwelling. Boiler House consumption refers to the conversion in boilers serving large single buildings or groups of buildings. District Heating consumption refers to the fuel input to the Heating Plant boilers.

Table 2.2 - Heating Plant/User Energy Consumption Metering Comparison

\begin{tabular}{|c|c|c|c|c|c|c|c|c|c|}
\hline \multirow[t]{2}{*}{$\begin{array}{l}\text { HX } \\
\text { Station }\end{array}$} & \multirow{2}{*}{$\begin{array}{l}\text { Heating Plant } \\
\text { Measurement } \\
\text { [G.Al }\end{array}$} & \multirow{2}{*}{$\begin{array}{l}\text { Measurement } \\
\text { (G) }\end{array}$} & \multicolumn{2}{|c|}{ Sosses in } & \multirow{2}{*}{$\begin{array}{l}\text { Total } \\
\text { Spacer } \\
\text { Heating } \\
\text { [Gd] }\end{array}$} & \multirow{2}{*}{$\begin{array}{l}\text { Water } \\
\text { reating }\end{array}$} & \multirow{2}{*}{ 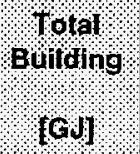 } & \multicolumn{2}{|c|}{ Bifference } \\
\hline & & & [G] & {$[\%]$} & & & & I94) & 1\%] \\
\hline 1 & 23826 & 17979 & 1618 & 9.0 & 19597 & 3681 & 23278 & 548 & 2.30 \\
\hline 2 & 13744 & 10797 & 971 & 9.0 & 11768 & 1574 & 13342 & 402 & 2.92 \\
\hline 3 & 4660 & 3115 & 214 & 6.9 & 3329 & 489 & 3818 & 842 & 18.07 \\
\hline 4 & 20520 & 17261 & 1208 & 7.0 & 18469 & 1754 & 20223 & 297 & 1.45 \\
\hline 5 & 45461 & 31462 & 2202 & 7.0 & 33664 & 6034 & 39698 & 5763 & 12.68 \\
\hline 7 & 2810 & 2208 & 155 & 7.0 & 2363 & 50 & 2413 & 397 & 14.13 \\
\hline 8 & 8732 & 6327 & 443 & 7.0 & 6770 & 8129 & 8129 & 603 & 6.91 \\
\hline Tolal & 19758 & 6811 & 6811 & & 95960 & 14941 & 41000 & 8852 & 789 \\
\hline
\end{tabular}

Table 2.3 - Total Primary Fuel Input for the Production of Heat Energy, 1992

\begin{tabular}{|c|c|c|c|c|c|}
\hline \multirow{2}{*}{ eansumption } & \multirow{2}{*}{ ron } & \multirow{2}{*}{ 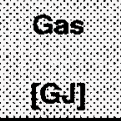 } & \multirow{2}{*}{$\begin{array}{l}\text { flect } \\
\text { entergy } \\
\text { rest }\end{array}$} & \multicolumn{2}{|c|}{ 10,al } \\
\hline & & & & {$[\mathrm{s}]$} & $\%$ \\
\hline On-Site & 29,599 & 67,000 & 2,884 & 99,483 & 3.41 \\
\hline Boiler Plants & 11,080 & 4,737 & 0 & 15,817 & 8.94 \\
\hline Heating Plant & 709,283 & 109,027 & 0 & 818,310 & 87.65 \\
\hline TOTAL & 749962 & 180764 & 2684 & 980610 & \\
\hline$\%$ & 8083 & 1036 & 9 & & \\
\hline
\end{tabular}

This table shows that approximately $88 \%$ of the fuel input in the town is consumed by the Heating Plant and that approximately $80 \%$ of the fuel input is in the form of solid fuel - coal.

The utilization of the 933,610 GJ of primary energy contained in the fuel input is shown in Table 2.4 . 
Table 2.4 - Primary Heat Energy Utilization, 1992

\begin{tabular}{|c|c|c|c|c|}
\hline \multirow[t]{2}{*}{ Energy Use } & \multirow{2}{*}{$\begin{array}{l}\text { Consumption } \\
\text { [GJYYear] }\end{array}$} & \multirow{2}{*}[\%]{} & \multicolumn{2}{|c|}{ Oistrict heat Only } \\
\hline & & & [GJJ' rear] & {$[\%]$} \\
\hline $\begin{array}{c}\text { Space \& Water Heating } \\
\text { Residential }\end{array}$ & 331,340 & 35.5 & 251,033 & 30.7 \\
\hline Non-Residential & 109,605 & 11.8 & 92,054 & 11.3 \\
\hline Industrial & 107,671 & 11.5 & 107,671 & 13.1 \\
\hline $\begin{array}{r}\text { Direct Heat Losses } \\
\text { Heat Plant }\end{array}$ & 275,778 & 29.5 & 275,778 & 33.7 \\
\hline Primary Distr. & 91,774 & 9.8 & 91,774 & 11.2 \\
\hline $\begin{array}{l}\text { Other Non-DH Conversion Losses } \\
\text { Residential }\end{array}$ & 15,062 & 1.6 & 0 & \\
\hline Non-Residential & 2,380 & 0.3 & 0 & \\
\hline TOIAL & 933.610 & 100 & 818.010 & 100 \\
\hline
\end{tabular}

It can be seen in Table 2.4 that $35.5 \%$ of the primary energy is used for space and water heating in the residential sector, $23 \%$ is used by the other sectors and $39.3 \%$ is lost in the heating plant and in the primary distribution system. Only about $2.2 \%$ of the primary energy is being lost in the non-District Heating conversion losses. Figure 2.7 illustrates the thermal energy flow in district heating system. 
Figure 2.7 - District Heat Energy Flow

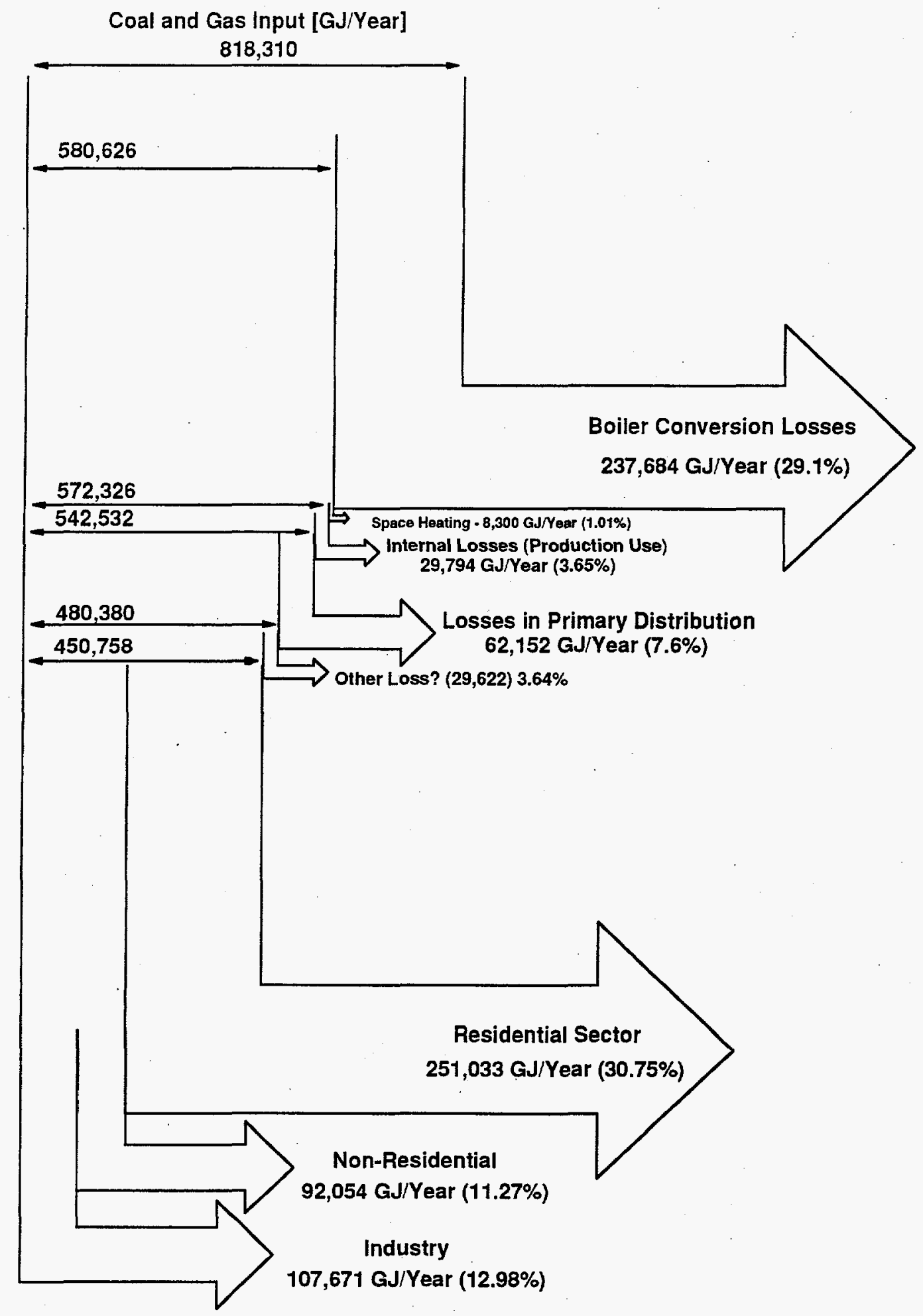




\subsubsection{Energy Consumption By Sectors}

Thermal energy consumption in Handlova is used almost exclusively in all sectors for space and water heating. Energy consumption by sectors and fuels is summarized in Table 2.5 .

Table 2.5 - Energy End Use by Sectors and Fuels

\begin{tabular}{|c|c|c|c|c|c|}
\hline \multirow{2}{*}{$\mathrm{FUEL}$} & \multicolumn{3}{|c|}{ SECTORS } & \multicolumn{2}{|c|}{ TOTAL } \\
\hline & Residential & Residential & Industrial & [GJ/Year] & [06] \\
\hline $\begin{array}{l}\text { LOCAL: } \\
\text { Coal } \\
\text { Gas } \\
\text { Electr. }\end{array}$ & $\begin{array}{r}29,599 \\
66,950 \\
1,200\end{array}$ & $\begin{array}{r}0 \\
50 \\
1,684\end{array}$ & $\begin{array}{l}0 \\
0 \\
0\end{array}$ & $\begin{array}{r}29,599 \\
67,000 \\
2,884\end{array}$ & $\begin{array}{r}5.2 \\
11.9 \\
0.5\end{array}$ \\
\hline $\begin{array}{c}\text { BOILER HOUSES: } \\
\text { Coal } \\
\text { Gas }\end{array}$ & $\begin{array}{l}0 \\
0\end{array}$ & $\begin{array}{r}11,080 \\
4,737\end{array}$ & $\begin{array}{l}0 \\
0\end{array}$ & $\begin{array}{r}11,080 \\
4,737\end{array}$ & $\begin{array}{l}2.0 \\
0.8\end{array}$ \\
\hline DISTRICT H & 251,033 & 92,054 & 107,671 & 450,758 & 79.6 \\
\hline TOTAL & 348782 & 109605 & 10767 & 566,058 & 100 \\
\hline$\%$ & 6116 & 10.4 & 190 & 100 & 100 \\
\hline
\end{tabular}

Nearly $62 \%$ of the net delivered energy (fuel input less losses in conversion and transit) is consumed by the residential sector. More detailed energy consumption data are presented in the following subsections. Industrial consumption represents about $19 \%$ and the non-residential sector also about $19 \%$. District Heat is the major energy source for space and water heating, representing $79.6 \%$ of the total energy consumption.

\subsubsection{Residential Sector Energy Consumption}

Data on the residential sector space heating and water heating are presented in Table 2.6 and Table 2.7 respectively. For each of the seven identified building types, the energy use, heated area and Energy Utilization Intensity (EUI) are shown for each of the fuel types. Space heating accounts for approximately $83 \%$ of the consumed energy and water heating for $17 \%$. 
Table 2.6 - Residential Sector Space Heating Energy Consumption By Building Type and Fuel

\begin{tabular}{|c|c|c|c|c|c|c|c|c|c|c|c|c|c|c|c|}
\hline \multirow{2}{*}{ Broup } & \multicolumn{4}{|c|}{ Energy Uso } & \multirow[t]{2}{*}{ Total } & \multicolumn{4}{|c|}{ Heated Area } & \multirow{2}{*}{$\begin{array}{l}\text { Heated } \\
\text { Area } \\
\text { Total }\end{array}$} & \multicolumn{4}{|c|}{$\begin{array}{l}\text { Energy Use Iniensity } \\
\text { [G./m] }\end{array}$} & \multirow{2}{*}{$\begin{array}{l}\text { Energy } \\
\text { Use } \\
\text { ntensity } \\
\text { Tolal }\end{array}$} \\
\hline & bist & 8081 & Gas & Electi & & Ossit & Coal & Gas & Electr & & Bisto & Coal & Gas & Electr & \\
\hline 1 & 0 & 0 & 9065 & 0 & 9065 & 0 & 0 & 12517 & 0 & 12517 & 0.000 & 0.000 & 0.724 & 0.000 & 0.724 \\
\hline 2 & 63552 & 397 & 5508 & 0 & 69457 & 70471 & 632 & 7943 & 0 & 79046 & 0.902 & 0.628 & 0.693 & 0.000 & 0.879 \\
\hline 3 & 74900 & 0 & 0 & 0 & 74900 & 89719 & 0 & 0 & 0 & 89719 & 0.835 & 0.000 & 0.000 & 0.000 & 0.835 \\
\hline 4 & 19106 & 0 & 0 & 0 & 19106 & 20639 & 0 & 0 & 0 & 20639 & 0.926 & 0.000 & 0.000 & 0.000 & 0.926 \\
\hline 5 & 46171 & 0 & 0 & 0 & 46171 & 54947 & 0 & 0 & 0 & 54947 & 0.840 & 0.000 & 0.000 & 0.000 & 0.840 \\
\hline 6 & 0 & 300 & 10931 & 0 & 11231 & 0 & 694 & 18412 & 0 & 19106 & 0.000 & 0.432 & 0.594 & 0.000 & 0.588 \\
\hline 7 & 0 & 19335 & 23579 & 900 & 43814 & 0 & 24421 & 34069 & 2511 & 61001 & 0.000 & 0.792 & 0.692 & 0.358 & 0.718 \\
\hline TOTAL & 208729 & 20032 & 49083 & 900 & 27374 & $2357 \%$ & 25747 & 72941 & 251 & 336975 & & & & & \\
\hline
\end{tabular}

Table 2.7 - Residential Sector Water Heating Energy Consumption By Building Type and Fuel

\begin{tabular}{|c|c|c|c|c|c|c|c|c|c|c|c|c|c|c|c|}
\hline \multirow[t]{2}{*}{ Group } & \multicolumn{4}{|c|}{ Energy Use } & \multirow[t]{2}{*}{$104 a$} & \multicolumn{4}{|c|}{ Heated 1 area } & \multirow{2}{*}{ Heated } & \multicolumn{4}{|c|}{ Energy Use lontensity } & \multirow{2}{*}{$\begin{array}{c}\text { Energy } \\
\text { ustensity } \\
\text { rotal }\end{array}$} \\
\hline & oisis & ooal & Gas & $\mathrm{Eled}$ & & Disty & 603 & Gas & Elestr & & Qistr & cool & Gas & Electr & \\
\hline 1 & 0 & 0 & 2265 & 0 & 2265 & 0 & 0 & 12517 & 0 & 12517 & 0.000 & 0.000 & 0.181 & 0.000 & 0.181 \\
\hline 2 & 6266 & 98 & 969 & 0 & 7332 & 70471 & 632 & 7943 & 0 & 79046 & 0.089 & 0.154 & 0.122 & 0.000 & 0.093 \\
\hline 3 & 23505 & 0 & 0 & 0 & 23505 & 89719 & 0 & 0 & 0 & 89719 & 0.262 & 0.000 & 0.000 & 0.000 & 0.262 \\
\hline 4 & 4512 & 0 & 0 & 0 & 4512 & 20639 & 0 & 0 & 0 & 20639 & 0.219 & 0.000 & 0.000 & 0.000 & 0.219 \\
\hline 5 & 13020 & 0 & 0 & 0 & 13020 & 54947 & 0 & 0 & 0 & 54947 & 0.237 & $0: 000$ & 0.000 & 0.000 & 0.237 \\
\hline 6 & 0 & 5 & 2176 & 0 & 2251 & 0 & 694 & 18412 & 0 & 19106 & 0.000 & 0.108 & 0.118 & 0.000 & 0.118 \\
\hline 7 & 0 & 1995 & 2414 & 300 & 4709 & 0 & 24421 & 34069 & 2511 & 61001 & 0.000 & 0.082 & 0.071 & 0.119 & 0.077 \\
\hline Torat & 47308 & 2168 & 7824 & 800 & 57595 & 235776 & 2574 & \%2941 & 2511 & 336975 & & & & & \\
\hline
\end{tabular}




\subsubsection{Non-Residential Sector Energy Consumption}

The energy demand by the non-residential sector is presented in Table 2.8. The District Heat is the largest source of thermal energy and represents $84 \%$ of the total energy consumption by this sector. The largest single energy demand group is Education (local schools), representing $47.1 \%$ of the sector demand.

Table 2.8 - Non-Residential Space and Water Heating Energy Consumption By Building Type and Fuel

\begin{tabular}{|c|c|c|c|c|c|c|c|c|}
\hline \multirow[t]{2}{*}{ GROUP } & \multicolumn{3}{|c|}{$\mathrm{LOAAL}$} & \multicolumn{2}{|c|}{ BOLLERHOUSE } & \multirow{2}{*}{$\mathrm{BHSTHST}$} & \multicolumn{2}{|c|}{ 1०1AL } \\
\hline & Coal & Gas & Electr & coal & Gas & & $161 / n$ & 101 \\
\hline NonRes-1 Education & 0 & 0 & 1,097 & 5,000 & 0 & 45,565 & 51,662 & 47.1 \\
\hline NonRes-2 Culture & 0 & 0 & 0 & 0 & 0 & 5,312 & 5,312 & 4.8 \\
\hline NonRes-3 Health & 0 & 0 & 200 & 0 & 0 & 19,531 & 19,731 & 18.0 \\
\hline NonRes-4 Sport & 0 & 0 & 0 & 6,080 & 0 & 5,850 & 11,930 & 10.9 \\
\hline NonRes-5 Offices & 0 & 0 & 0 & 0 & 0 & 928 & 928 & 0.8 \\
\hline NonRes-6 Services & 0 & 50 & 387 & 0 & 4,737 & 9,687 & 14,861 & 13.7 \\
\hline NonRes-7 Hotels & 0 & 0 & 0 & 0 & 0 & 5,181 & 5,181 & 4.7 \\
\hline TOTAL & 0 & 50 & 1,684 & 11,080 & 4,737 & 92,054 & 109,605 & 100 \\
\hline$[\%]$ & 0 & .1 & 1.5 & 10.1 & 4.3 & 84.0 & 100 & 100 \\
\hline
\end{tabular}

\subsubsection{Industrial Sector Energy Consumption}

The industrial sector in Handlova uses exclusively District Heating System as a source of thermal energy for space and water heating. Table 2.9 below shows the industrial energy users and the amount of energy they consume.

Table 2.9 - Industrial User Energy Consumption

\begin{tabular}{|c|c|c|}
\hline \multirow[t]{2}{*}{ USER } & \multicolumn{2}{|c|}{ OISTRIOT GEAT } \\
\hline & IGY Yoal & \%1] \\
\hline Coal Mine & 76,736 & 71.3 \\
\hline Chemika & 5,684 & 5.2 \\
\hline Lahke Konstrukcie & 19,177 & 17.8 \\
\hline Slovenka & 2,114 & 2.0 \\
\hline AMK & 188 & 0.2 \\
\hline CSD Station & 2,079 & 1.9 \\
\hline State Farm & 1,693 & 1.6 \\
\hline TOTAL & 10\%,6\%? & 100 \\
\hline
\end{tabular}




\subsection{DEMAND FORECAST}

This section develops the three variants for energy demand growth used for the study. Assuming a 25 year life for the heat supply equipment to be built by 1997, the energy demand was projected to the year 2022 .

Variant 1:

This variant assumes no change in thermal energy demand in both the residential and nonresidential sectors and assumes detachment of the industrial sector from the District Heating system.

Under this variant, energy demand will, for space heating and water heating in both the residential and non-residential sectors, remain on the 1992 level of 458,387 GJ/Year. The industrial sector will be served by its own sources, but the annual consumption would remain the same at $107,671 \mathrm{GJ} / Y e a r$. This variant represents the lowest possible energy demand.

\section{Variant 2:}

This variant was based on the Urban Development Plan for the Town of Handlova performed by AGS Atelier for the Town Hall in 1993. This study predicted the town population would increase from 18,332 in 1992 to 19,500 in a year 2010. By extrapolating the growth curve at a somewhat cautious rate, the town population was predicted to be 19,750 in 2022 . This is a population increase of approximately 1400 persons, or $5.22 \%$. Industrial activity in this variant was assumed to stay at the 1992 level with no increase in thermal energy demand.

Under these assumptions, energy demand for space heating and water heating would increase by $18,206 \mathrm{GJ}$, or $3.22 \%$ of the town energy demand in 1992. Increase in District Heating Demand is assumed $11,268 \mathrm{GJ}$, or $4.5 \%$

\section{Variant 3:}

This variant assumed greater population growth and increased industrial activity. Population growth was assumed to be $6 \%$ greater than predicted in Variant 1, for a total increase of $11.22 \%$ or 2057 persons. Industrial thermal energy demand was assumed to grow by $20 \%$ from the 1992 level.

For this variant, energy demand for residential space heating and water heating would increase by $39,133 \mathrm{GJ}$, or $6.91 \%$, and industrial thermal energy demand would increase by 21,534 GJ, or $3.80 \%$. Total energy demand would increase by $60,667 \mathrm{GJ}$, or $10.71 \%$ of the total demand in 1992. The District Heating Demand would increase by 24,247 GJ $(4.28 \%)$ due to population growth, and 23,287 GJ $(4.11 \%)$ due to industrial growth. 


\section{BUILDING SECTOR EFFICIENCY ASSESSMENT}

This section presents the estimated efficiency resource in the residential and nonresidential buildings and the industrial sectors. Section 3.1 describes the efficiency measures considered. Section 3.2 lists efficiency measures not considered. The technical analysis approach employed to estimate the efficiency resource is described in Section 3.3 and the economic analysis approach in Section 3.4. The building and industrial sector efficiency resource is presented in Section 3.5. Section 3.6 provides a brief discussion of the sensitivity of presented results on some input parameters.

\subsection{EFFICIENCY MEASURES}

Fifty energy conservation opportunities (ECOs) were considered for evaluation for the residential and non-residential building stock in Handlova. Of these, 24 ECOs were determined to be applicable to more than one building group and were analyzed with respect to energy efficiency potential, cost and availability on the Slovak market. A brief description of the ECO's follows:

\subsubsection{Energy Efficiency Measures Considered}

The 24 efficiency measures considered are presented by category of application: building envelope; domestic water heating; heating system; and ventilation and heat recovery.

\subsubsection{Building Envelope Measures}

Insulate Building Exterior Side Walls. Insulation installed on the exterior walls of the building improves the R-value of the building shell, and therefore, decreases the heat loss through the walls. Depending on the method used and material thickness, the R-value of the walls may be increased by 0.8 to $1.4 \mathrm{~m}^{2} \mathrm{~K} / \mathrm{W}$. Exterior insulation also results in increased exterior zone temperature by as much as 3 to $5^{\circ} \mathrm{C}$, thus indirectly reducing overheating of the building core space when building temperatures are properly adjusted. An additional positive effect is the elimination of moisture condensation on the interior side of the walls in cold weather. Although this ECO is widely used, poor workmanship causes the results to be less than expected in many installations.

Insulate Top Floor Ceiling. The top floor ceiling in many building types is poorly insulated, which results in a substantial heat loss from the top floor and higher space heat to compensate for this often causes overheating of the building core space. Insulating the top floor ceiling from the interior side is applicable to buildings with a flat roof, where adding insulation from the exterior side would require extensive effort to keep the insulation protected from the weather. The ceiling insulation is designed not to upset the appearance of the apartment interior and increases the Rvalue by 2.1 to $3.0 \mathrm{~m}^{2} \mathrm{~K} / \mathrm{W}$. 
Insulate Attic. Insulating the attic is a widely used method of reducing heat loss in a building with an attic space: The insulation may be installed in many different ways, such as blown into the attic, laid on the top of the ceiling, poured in a liquid state, etc. Fiberglass blankets or boards, and styrofoam boards are most commonly used. Depending on the method used, the Rvalue can be increased by as much as $3.5 \mathrm{~m}^{2} \mathrm{~K} / \mathrm{W}$.

Insulate Floor Above Basement. Insulating the floor above a cold basement or crawl space improves the floor R-value as well as occupant comfort, which typically results in a lower thermostat setting. Many floor covering materials with good thermal insulation properties are available. For floors with an air cavity, blown-in cellulose-based insulation is also available.

Weatherstrip Elevator Penthouse, Stainway, Doors and Windows. Reducing infiltration by sealing cracks around doors and windows in unheated spaces, such as stainways will increase the temperature in such spaces, thus reducing the heat loss from the heated space to unconditioned space. Eight to ten floor apartment buildings, which are approximately 22 to 28 meters high, can have a substantial draft through the stairway due to the stack effect. Sealing cracks in the upper part of the stairway substantially can reduce infiltration. The temperature on cold days may be increased by as much as $4^{\circ} \mathrm{C}$.

Weatherstrip Windows and Doors. Sealing cracks around windows and doors is a simple way to reduce infiltration to occupied spaces; thus reducing the energy required to heat ambient air entering the heated space. Windows, especially in older apartment buildings, which fit poorly result in significant levels of infiltration. In order to be functional, seals have to be properly installed and maintained.

Install Revolving or Double Door in Building Vestibule. Revolving or double doors reduce infiltration of ambient air into the unconditioned lobby or entrance space of the building as people enter or leave and also provide better sealing, thus increasing the unheated space temperature. Low thermal insulation of internal walls may have a significant effect on heat loss from the heated space. Revolving doors are especially good for high traffic entries, such as stores, banks, etc. Double doors are good for apartment buildings.

Install Triple Pane Windows. The fenestration area of the residential structures found in the Slovak Republic can be a significant fraction of the building envelope area. In some buildings, such as the $T-06-B$, the window area is $24 \%$ of the building shell surface. The U-value of the windows is 2.7 to 4.2 times greater than for walls. Subsequently, the heat loss through the windows are significant. Triple pane windows with high performance glass provide an improved $R$-value for the fenestration area and reduce heat loss through the glass. The $U$-value of a triple pane window is typically $1.6 \mathrm{~m}^{2} \mathrm{~K} / \mathrm{W}$, whereas the regularly used window has U-value of 2.6 to 2.8 $\mathrm{W} / \mathrm{m}^{2} \mathrm{~K} / \mathrm{W}$. It is also assumed that new windows will provide a tighter fit resulting in lower infiltration. 
Install Storm Windows. An additional layer of glass mounted in its own frame, either on the inside or outside of the existing window improves the total R-value of the fenestration area and reduces the infiltration. Storm windows may be installed seasonally or permanently. Compared with triple pane windows, this alternative offers smaller improvements of R-value, but at a lower installed cost.

Install Heat Reflectors Behind Each Radiator or Heater. Heat reflectors deflect the radiant portion of the heat otherwise absorbed by the wall (in most cases an exterior wall) into the heated space. The wall temperature behind the radiator is lowered and the R-value of the part of the wall covered by reflector is increased, thus reducing the heat losses. This is in many cases a "do-ityourself" inexpensive job.

Remove Draperies from Radiator. Radiators are typically located under the windows and covered by window draperies, especially during the evening and night hours. The draperies then form an air channel which forces the heated air leaving the radiator to flow closer to the window and thus create a local environment with higher temperatures. This increases the heat loss through the window. Removing draperies does not require any investments and will be most likely done by the occupant, providing he/she is responsible for the heating bill. An educational effort is required to implement this change.

\subsubsection{Domestic Water Heating}

Install Low-Flow Shower Heads. Low-flow shower heads are available on the market and can reduce of the required water flow by $17 \%$ to $50 \%$ without sacrificing user comfort. These shower heads create the same "massaging" effect as high water flow models. Shower heads are easy to install and do not require plumbing changes.

Install Flow Restrictors in Faucets. Reduce the flow of water in bathroom and kitchen faucets for washing, shaving, dish-washing etc. Installing flow-restricting orifices is simple and inexpensive and can be done by the occupant. The water consumption for the purposes described above can be reduced by up to $50 \%$.

Insulate Hot Water Pipes in Unconditioned Spaces. Hot water pipes are, in most cases, already insulated. However, the old insulation is typically insufficient, damaged or otherwise not functional. Additional or new insulation lowers the hot water heat loss.

Install Hot Water Flow Meters. This ECO assumes that the occupant is responsible for the hot water bill. Hot water flow meters, installed visibly at locations of hot water use, serve not only as energy allocation devices, but also makes the occupant much more aware of hot water consumption. Occupant awareness of energy use has proven to be an effective energy saver in many installations throughout Europe and the U.S. This ECO has been shown to result in a $7 \%$ energy reduction. 


\subsubsection{Heating System}

It is important to note that the heating systems found in multi-family residential building structures are designed with main branches and risers serving rooms in several apartments. For example, corner bedrooms on all floors are served by one riser, while comparably located living rooms on all floors are served by another riser. Without costly plumbing changes, this design does not allow control of the heating by a single zone valve for each apartment. Heat metering is also difficult for the same reason. Multiple zone valves and multiple heat allocation devices have to be used.

Balance Heating System Using Existing Valves. A properly balanced heating system should supply the correct amount of heat to each conditioned space to keep the temperature in that space within comfortable limits. In many cases heated spaces with higher heat losses, for example corner apartments, are receiving less than the required heat due to a poorly designed heating system. In order to keep the temperature within acceptable limits, the rest of the building, especially the core portion, is greatly overheated.

Manual regulating valves are normally installed on each radiator, but if not used for a prolonged period of time, they usually leak. The occupant is not willing to take that risk and would rather open a window to lower the room temperature. In many cases, the fact that the occupant is not accountable for the heating bill exaggerates this problem.

In some buildings the system balancing can be done by using existing balancing valves installed on risers or branches of the plumbing system. It is a very effective, low cost ECO. Balancing should be done periodically.

Install Balancing Valves on Each Radiator. This improvement is applicable to the systems where balancing valves were not originally provided. Balancing valves installed on each radiator will allow more accurate distribution of the heat throughout the building. However, this measure does not provide the occupant the ability to control the room temperature.

Install Thermostatic Radiator Valves (TRVs). Installing a TRV on each radiator provides the user with the capability to control the temperature within reasonable temperature fluctuations. In order to be an effective ECO, the TRVs have to be installed together with heat allocation devices and a building GJ-meter for proper allocation of heating cost. TRVs alone do not provide an incentive for savings, and in many cases, they are left fully open all the time. Controlled room temperature (and allocating energy cost) also discourages the occupant from unnecessarily opening windows, thus significantly reducing the infiltration rate.

Install Zone Valves on Each Radiator and Install Central Thermostat with "ON Time Counter" in Each Apartment. Zone valves, installed on each radiator and controlled by a single thermostat located centrally in the apartment, provide excellent temperature control with good accuracy. Temperature in the apartment is controlled more tightly than with TRVs, and the 
operation of the thermostat is more "user-friendly". A thermostat with an electronic "On-Time counter" can be used instead of cumbersome evaporative type heat allocation devices. The use of a building level GJ-meter is also assumed with this measure.

Install Zone Valves on Each Radiator and Install Central Programmable Thermostat with TOD and "ON-Time" Counter in Each Apartment. An additional feature of this ECO, as compared to the prior ECO, is the capability to program the thermostat to maintain the room temperature based on occupancy for a one or two week period. Lowering the temperature during the unoccupied period can save a significant amount of energy. The use of a building level GJ-meter is also assumed with this measure.

Install Building Energy Management System (EMS). An Energy Management System tailored for a specific building or group of buildings provides the most energy savings in this category. An apartment building consisting of 40 to 50 living units can save as much as $48 \%$ of the space heating energy when controlled by an EMS. The EMS controls the energy source to provide optimal temperature of the heating media and controls the space temperatures allowing occupants to set the temperature in each zone. The EMS also collects energy use information and, for billing purposes, is accessible by the utility through the phone line. The cost of such systems may be prohibitive at existing energy costs in Slovakia.

\subsubsection{Ventilation and Heat Recovery}

Install Heat Recovery Vent System in Basements. Typically, the basements in apartment buildings serve as storage spaces for bicycles and baby-carriages, laundry rooms, etc. The basement is vented through permanently open ventilation windows. Installation of a heat recovery unit, which provides fresh air to the storage spaces at $90 \%$ heat recovery efficiency, (providing all cracks, openings for piping, etc. and broken windows are sealed) may increase the basement temperature during cold days by as much as $3^{\circ} \mathrm{C}$.

Install Waste Water Heat Recovery Heat Exchanger. Utilizing the heat from waste water for preheating the cold water entering the hot water heater results in a sizable reduction of the heater capacity required for water heating. Apartment buildings with central water sewage pipes are the ideal candidates for such an ECO, but this method is applicable to all building groups. Up to $25 \%$ of heat required for water heating can be saved.

Install Bath/Kitchen Vent Heat Recovery Heat Exchanger. Open ventilation ducts from kitchens and bathrooms in apartment buildings cause unnecessary infiltration. Installing air dampers which operated with the exhaust fans and installing heat recovery heat exchangers prevent unnecessary infiltration and provide controlled air retum with up to $90 \%$ heat recovery. 


\subsubsection{Efficiency Measures Not Considered}

A number of Energy Conservation Opportunities identified were not considered for further evaluation because: they did not offer an adequate level of efficiency improvement potential; they could only be addressed through a more focused data collection effort beyond the scope of this effort; they would address only a small part of the building stock; and/or they were applicable to the energy supply side. The ECO's applicable to residential buildings that were not considered are presented in this subsection by ECO category.

\subsubsection{Building Envelope}

Insulate roofs with no attic space. Installing exterior insulation on flat and tile roofs is expensive, as this essentially requires the installation of a new roof and the need to ensure the roof is waterproof. Additional data collection would also have been required to evaluate this measure.

Internal insulation of walls. This measure is expensive to implement, affects the appearance of the interior, and imposes a considerable burden on the occupant.

Insulate roof panel cavities. Adding insulation may reduce or eliminate cavity ventilation and possibly create moisture condensation inside the cavity.

Insulate exterior walls of historical buildings and single and two family homes. This was rejected as unacceptable for the historic buildings and too expensive for the other building groups.

Insulate apartment building exterior walls having windows. This was considered too expensive to do in a manner that would be acceptable from an appearance standpoint.

Insulate internal walls between heated and unheated spaces (staimays). This was not considered to provide sufficient efficiency improvement and would have required additional data collection and analysis to evaluate.

Insulate basement perimeter above the ground. This was not considered to provide sufficient efficiency improvement and would have required additional data collection and analysis to evaluate.

Repair leaking roofs which cause wet walls and insulation to become ineffective. This was not considered to be a common measure and would have required additional data collection and analysis to evaluate. 


\subsubsection{Domestic Water Heating}

Replacing electric water heaters with gas or LP gas water heaters. This was not considered to be a common measure and would have required additional data collection and analysis to evaluate.

Insulate hot water pipes in conditioned space. This was not considered to be a cost effective measure and would have required additional data collection and analysis to evaluate.

Lower hot water temperatures. Domestic water temperature is maintained at $55^{\circ} \mathrm{C}$ and lowering the temperature may introduce a health hazard.

Use of cold water for laundry washing. Detergents effective in cold water are not yet available.

Install overhead showers to promote use of showers. Bathing in a tub is common and would require significant effort to effect a lifestyle change.

\subsubsection{Heating System}

Re-work building heating system plumbing. Re-design and re-work the building heating system to allow a single control and energy consumption measurement point for each apartment was not considered cost-effective.

Replace or improve existing gas or coal room heaters. This was not considered to be a common measure and would have required additional data collection and analysis to evaluate.

Insulate boilers and water heaters to reduce standby losses. This would have required additional data collection and analysis to evaluate.

Fuel switching. A supply related measure beyond the scope of this analysis.

Replacing circulating pumps and temperature and flow control components with high performance parts. This would have required additional data collection and analysis to evaluate.

Insulation of conduits between boiler or heat exchanger and building. This would have required additional data collection and analysis to evaluate.

Application of heat pumps for space and water heating. The Czech climate would require a ground source heat pump for efficient operation. Additional data collection and analysis would have been required to evaluate heat pump water heaters. 
Application of thermal storage. Too expensive and additional data collection and analysis would have been required to evaluate.

Application of non-conventional energy sources, such as solar, geothermal, waste heat from local industry etc. This was not considered to be a common measure and would have required additional data collection and analysis to evaluate.

Improved maintenance (cleaning) of the heat sources, such as local boilers, room heaters, etc. This would have required additional data collection and analysis to evaluate.

Installation of supply water temperature reset control systems. This would have required additional data collection and analysis to evaluate.

\subsubsection{Ventilation and Heat Recovery}

Installation of indoor air quality ventilation/heat recovery units. High efficiency heat recovery ventilation units in each room or apartment would introduce fresh air into the space with approximately a $90 \%$ heat recovery rate. The cost of such units was not considered cost-effective.

Install combustion air preheating for local heaters. A supply related measure beyond the scope of this analysis.

\subsubsection{Summary of Efficiency Measures Considered}

Table 3.1 summarizes the 24 efficiency measures considered by cost-per-unit of application and measure lifetime.

\subsection{ANALYSIS APPROACH}

The 24 measures were analyzed for the seven residential building types by the four fuel and equipment types identified: on-site gas, on-site coal, district heat, and electricity. Measures were not analyzed for electric space heating as this represents only $0.5 \%$ of the total heating load. Measures were considered for application to electric water heat. 
A possibility not analyzed is that base space and water heat use may increase due to increases in living standards. Should base use increase, the efficiency potential will also increase.

The weather data required for computation of building loads and energy savings were not available for Handlova, Slovakia, so weather data for Prague, Czech Republic was used for the load calculations. Saving potential results were then adjusted based on average monthly temperature ratio of both locations.

The technical analysis approach for developing the estimated per measure efficiency improvement for each measure category is described in Section 3.2.1. The economic analysis method is discussed in Section 3.2.2.

\subsubsection{Technical Analysis Method}

The analysis method applied to each category of efficiency measures is described in this subsection

\subsubsection{Analyses of Building Envelope Measures}

The ASEAM3 (A Simplified Energy Analysis Method, Version 3.0) computer program for simulating heat losses in buildings based on procedures recommended by the American Society For Heating, Refrigeration and Air Conditioning Engineers (ASHRAE) Fundamentals was used for the analysis. The program provides prediction of maximum heat loads, annual energy consumption, and the effect of other factors on building heat loads (occupancy, lighting, appliances usage, insolation, etc.)

Baseline and post-measure installation heat loss was calculated for each measure. The difference between the two heat loss values is the energy savings. The development of the baseline building heating loads for each building type required making several assumptions. The most important were infiltration rates, internal temperatures in different locations, and occupancy and equipment schedules. These assumptions were based on recommended values, previous experience and information gathered by survey (number of opened windows in apartments in occupied and unoccupied periods). 
Table 3.1 - Efficiency Measures Considered and Estimated Per Unit Cost and Lifetime

\begin{tabular}{|c|c|c|c|c|}
\hline Number & Energysaving Option Desarption & Unit & Costotst & Hetrons \\
\hline \multicolumn{5}{|c|}{ Building Envelope } \\
\hline 1 & Insulate Exterior Side Walls & $\mathrm{m}^{2}$ & $700-800$ & 30 \\
\hline 2 & Insulate Top Floor Ceiling & $\mathrm{m}^{2}$ & 700 & 30 \\
\hline 3 & Insulate Attic & $m^{2}$ & -385 & 30 \\
\hline 4 & Insulate Floor Above Basement & $\mathrm{m}^{2}$ & 120 & 30 \\
\hline 5 & $\begin{array}{l}\text { Weatherstrip Elevator Penthouse, Stairway, Doors and } \\
\text { Windows }\end{array}$ & $\mathrm{m}$ & 40 & 10 \\
\hline 6 & Weatherstrip Doors and Windows & $\mathrm{m}$ & 40 & 10 \\
\hline 7 & Install Revolving or Double Door in Building Vestibule & Unit & 30,000 & 30 \\
\hline 8 & Install Triple Pane Windows & $m^{2}$ & 5409 & 30 \\
\hline 9 & Install Storm Windows & $m^{2}$ & 600 & 30 \\
\hline 10 & $\begin{array}{l}\text { Install Heat Reflectors Behind Each Radiator or } \\
\text { Heater }\end{array}$ & $m^{2}$ & 148 & 5 \\
\hline 11 & Remove Draperies from Radiator & & 0 & \\
\hline \multicolumn{5}{|c|}{ Domestic Water Heating } \\
\hline 12 & Install Low-Flow Water Heads & Unit & 250 & 10 \\
\hline 13 & Install Flow Restrictors in Faucets & Unit & 70 & 5 \\
\hline 14 & Insulate Hot Water Pipes in Unconditioned Spaces & $\mathrm{m}$ & 158 & 15 \\
\hline 15 & Install Hot Water Flow Meters & Unit & 900 & 30 \\
\hline \multicolumn{5}{|c|}{ Heating System } \\
\hline 16 & Balance Heating System Using Existing Valves & Flat & 400 & 5 \\
\hline 17 & Install Balancing Valves on Each Radiator & Unit & 350 & 15 \\
\hline 18 & $\begin{array}{l}\text { a. Install Thermostatic Radiator Valves } \\
\text { b. Install Heat Allocators/Meters } \\
\text { c. Install Building Level GJ Meter }\end{array}$ & $\begin{array}{l}\text { Unit } \\
\text { Unit } \\
\text { Unit }\end{array}$ & $\begin{array}{c}650 \\
100 \\
10000-40000 \\
\end{array}$ & $\begin{array}{c}15 \\
1 \\
30\end{array}$ \\
\hline 19 & $\begin{array}{l}\text { a. Install Zone Valves on Each Radiator } \\
\text { b. Install Central Thermostats with On-Time } \\
\text { Counter in Each Flat } \\
\text { c. Install Building Level GJ Meter }\end{array}$ & $\begin{array}{l}\text { Unit } \\
\text { Unit } \\
\text { Unit }\end{array}$ & $\begin{array}{r}330 \\
2300 \\
24000-46000 \\
\end{array}$ & $\begin{array}{l}15 \\
15 \\
30 \\
\end{array}$ \\
\hline 20 & $\begin{array}{l}\text { a. Install Zone Valves on Each Radiator } \\
\text { b. Install Central Programmable Thermostats } \\
\text { with On-Time Counter in Each Flat } \\
\text { c. Install Building Level GJ Meter }\end{array}$ & $\begin{array}{l}\text { Unit } \\
\text { Unit } \\
\text { Unit }\end{array}$ & $\begin{array}{c}330 \\
6120 \\
24000-46000 \\
\end{array}$ & $\begin{array}{l}15 \\
15 \\
30 \\
\end{array}$ \\
\hline 21 & Install Building Energy Management System (EMS) & $\begin{array}{c}\text { Unit- } \\
\text { Radiator }\end{array}$ & 7000 & 30 \\
\hline \multicolumn{5}{|c|}{ Ventilation and Heat Recovery } \\
\hline 22 & $\begin{array}{l}\text { a. Install Heat Recovery Vent System in } \\
\text { Basements } \\
\text { b. Weatherstrip Basement Windows and Doors }\end{array}$ & $\begin{array}{l}\text { Unit } \\
m\end{array}$ & $\begin{array}{c}7600 \\
40\end{array}$ & $\begin{array}{l}10 \\
10\end{array}$ \\
\hline 23 & Install Waste Water Heat Recovery Heat Exchanger & Unit & $10200-126000$ & 15 \\
\hline 24 & $\begin{array}{l}\text { a. Install Bath/Kitchen Vent Heat Recovery Heat } \\
\text { Exchanger } \\
\text { b. Install Back-Flow Damper in Kitchen/Bath } \\
\text { Vent Duct }\end{array}$ & $\begin{array}{l}\text { Unit } \\
\text { Unit }\end{array}$ & $\begin{array}{c}9050 \\
350\end{array}$ & $\begin{array}{l}10 \\
15\end{array}$ \\
\hline
\end{tabular}


In the modeling of each ECO, only the pertinent value describing the given ECO was changed in the model. Insulation of walls, ceilings and floors were modeled by lower U-values; weatherstripping windows was modelled by lowering the infiltration coefficient; installing triple pane and storm windows was accomplished by lowering the window U-value; weatherstripping stainway windows and doors, and installing entrance double doors was modelled by increasing the unheated space temperature; and installation of a heat recovery unit for the bath/kitchen was accomplished by reducing the infiltration rate.

\subsubsection{Analyses of Water Heating Measures}

Energy saving calculations for low flow shower heads and faucet flow restrictors are based on statistical information regarding the use of hot water in the Czech Republic, statistical information on hot water use by purpose (dish-washing, shower, laundry, etc.), and manufacturers performance information. The calculation of energy savings is obtainable by insulating the hot water pipes in unconditioned spaces is based on lowering heat losses by additional pipe insulation with improved R-value or replacement of existing insulation with high performance materials. Due to the limited nature of this project, exact length and sizes of pipes could not be determined, but rather were estimated for each building group based on typical plumbing designs.

\subsubsection{Analyses of Building Heating System}

All ECOs analyzed in this category provide improved energy management in the building. Installation of temperature control devices (TRV,TS, EMS) in conjunction with installation of energy cost allocation equipment provide building occupants with an incentive to reduce energy consumption. The use of a programmable thermostat also improves the use of setback during unoccupied periods. The combination of better energy management and distribution within the building and the ability of motivated occupants to lower the energy consumption results in two effects:

- room temperature is kept at the lowest acceptable level

- windows are opened only to maintain acceptable indoor air quality and not for temperature control.

The computerized calculations used for the building heating system energy saving measures were also derived from the procedures recommended by the (ASHRAE) Fundamentals. For each measure, both the baseline and post-measure installation heat loss was calculated. The difference between the two heat loss values is then the energy use reduction. For each ECO analyzed, the temperatures and infiltration rates were estimated based on the performance of the proposed equipment and expected occupant behavior. In general, more accurate equipment and more motivated occupants will produce lower temperatures and lower infiltration rates. The temperatures were not assumed to drop below accepted comfort limits (for example, $21 \mathrm{C}$ in living rooms and $18 \mathrm{C}$ in bedrooms). 


\subsubsection{Analyses of Ventilation and Heat Recovery Measures}

The energy saving calculations developed for the heat recovery applications were again derived from procedures recommended by the ASHRAE Fundamentals. Inputs to the calculations include properties and mass flow of media from which the waste heat is recovered and manufactures performance characteristics for the heat recovery equipment.

\subsubsection{Economic Analysis}

This section presents the economic analysis metrics, the economic assumptions, and the approach employed to assess the economic performance of the efficiency measures.

\subsubsection{Analysis Metrics}

The ECOs described in the previous section were analyzed in a number of ways, with the intent of presenting a variety of what are called "analysis metrics" for measuring the attractiveness of an ECO as an investment. A number of economic metrics commonly used to evaluated measure effectiveness are present value, net present value, simple payback, and levelized energy cost. These methods are described in this section.

Present Value and Net Present Value. Present values account for the fact that a crown today is worth more than a crown tomorrow, for two principal reasons: general price inflation and the time value of money. In the face of general price inflation, the purchasing power of a crown declines over time, and since the true value of money lies in what it is capable of purchasing, inflation causes its value to decline. The time value of money refers to the fact that even in the absence of general price inflation, money received sooner is preferred to money received later.

It is this preference for consuming sooner rather than later that leads to the existence of positive rates of interest, even in the absence of price level inflation. Individuals and firms are willing to pay a premium to obtain goods and services sooner rather than later: the premium they are willing to pay is the "real rate of interest". The market rate of interest, or the "nominal" rate, is the real rate plus the rate of inflation (this is a slight simplification). As an example, $100 \mathrm{SK}$ received two years from today is worth only 82.64 SK today, assuming a ten percent interest rate. Conversely, 82.64 SK invested today at ten percent per annum yields 100 SK two years later. 
The costs and the benefits of an efficiency investment occur at different periods of time, which must be accounted for in the analysis. The metric selected for this is net present value to calculate the present value of all of the costs associated with an $\mathrm{ECO}$, less the present value of all of the benefits of the ECO. The NPV is a measure of the total value of the energy efficiency investment and is used to define the cost-effectiveness of an ECO: a negative NPV means that the costs of an ECO outweigh its benefits, while a positive NPV means that the benefits are greater than the costs. The higher the NPV, the better.

Simple Payback. The most basic analysis metric used is the simple payback period, which, in it's simplest form is calculated by dividing the installed cost of the ECO by the value of the annual energy savings. The simple payback period is then the number of years required for the savings resulting from an investment in energy efficiency to offset the cost of the investment: thus, the lower the payback period, the more attractive the investment.

In many analysis situations, this metric is to simplistic to be of much use. ECO's with future costs may be overvalued if these costs are not accounted for. Escalating fuel prices will undervalue the ECO. Simple payback does not enable ready comparison for measures having different useful lives. This method also does not account for the time value of money and may not be readily comparable with other investments using more sophisticated measures of value.

Levelized Energy Cost. A slightly more complex metric is the levelized energy cost (LEC), also called the cost of conserved energy, expressed in crowns per gigajoule. The LEC is the total cost of an ECO over the measure life, converted to an annual value (the installed cost is "levelized", from a lump sum into a series of equal annual payments), divided by the annual energy savings in gigajoules. The LEC is used to compare the cost of the energy resource obtained through conservation with the cost of energy from other sources, such as purchasing energy from the district heat system, or purchasing coal for use in on-site boilers. The LEC allows the calculation of a supply curve for energy efficiency. The supply curve shows the total annual energy conservation resource available at any given cost per unit of energy conserved. Using the supply curve, it is possible to determine the conservation resource available for less than or equal to the cost of competing resources, such as coal, district heat systems, or natural gas.

Economic Assumptions. Two types of economic analysis methods typically used are nominal and real. A nominal analysis is performed using current money values, reflecting the effects of inflation. The value of energy savings in 1993 is expressed in money with 1993 purchasing power, the value of energy savings in 1994 is expressed in money. with 1994 purchasing power, and so on. The value of the energy savings continues to increase, because of inflation in the general level of prices. A real analysis expresses all money values in constant terms by removing the effects of inflation. In the case of this analysis, all values are expressed in 1993 currency values.

The implications of using a real analysis are the need to calculate a real discount rate, which is basically the interest rate after the effects of inflation have been removed. For the 
purposes of this analysis, a simplification was used, whereby the real discount rate is calculated as the nominal interest rate minus the expected rate of inflation.

In driving the economic analysis, three sets of assumptions were employed for evaluating the cost-effectiveness of the efficiency measures by the economic metrics. These consist of base economic assumptions and three fuel price levels.

Base Assumptions. The base economic assumptions underlying the analysis are shown in Table 3.2 .

Table 3.2 - Base Economic Assumptions for Analysis of Efficiency Measures

\begin{tabular}{||l|c|}
\hline Nominal Discount Rate & $17.5 \%$ \\
\hline Expected Inflation & $8.0 \%$ \\
\hline Real Discount Rate & $9.5 \%$ \\
\hline Analysis Period & 30 years \\
\hline
\end{tabular}

Alternate Fuel Prices. Energy prices are currently subject to some form of regulation and/or subsidy, both of which will be modified in the near future. In addition, district heating system will either have to be upgraded or replaced by the decentralized system. Each of these alternatives will result in different energy price. Therefore, the four fuel price levels were developed for investigation of the impact of likely changes in near term energy prices on the energy efficiency resource. This was done in conjunction with staff from the Town, Heating Plant, EGU, ZPZ and SEP. The prices are shown in Table 3.3.

Table 3.3 - Fuel Price Levels Used to Drive Analysis of Efficiency Resource and Sensitivity Analysis, by Fuel Type

\begin{tabular}{|c|c|c|c|c|}
\hline \multirow[b]{2}{*}{ FUEL TYPE } & \multicolumn{4}{|c|}{ FUEL PRIGE IEVEL } \\
\hline & Level/ & Level 2 & Tevel 3 & I levels 4 \\
\hline On-Site Gas & 80.00 & 108.00 & 150.00 & 270.00 \\
\hline On-site Coal & 55.00 & 80.00 & 100.00 & 150.00 \\
\hline Electricity & 222.00 & 250.00 & 300.00 & 350.00 \\
\hline District Heat & 165.00 & 210.00 & 270.000 & 300.00 \\
\hline
\end{tabular}


Level 1 represents the current, still subsidized fuel prices. Level 2 corresponds to the removal of subsidies, Level 3 corresponds to a more aggressive and most likely fuel price increase, and Level 4 roughly corresponds to West European absolute and relative fuel prices. At all four levels, the price increases are assumed to happen at the time of implementing energy conservation technologies. The price of coal is assumed to increase by $2.7 \%$ annually over the general inflation rate; price of gas is assumed to increase by $2.85 \%$ over the general inflation rate to the year 2005 and $1.4 \%$ annually after that year. The price of electricity is assumed to increase by $6 \%$ over the general inflation. Level 3 prices were used for the analysis in this report.

\subsection{BUILDING SECTOR EFFICIENCY ASSESSMENT RESULTS}

This section provides the energy and economic assessment of the 24 building sector efficiency measures considered for the analysis. The method employed to assess the efficiency potential consisted of four steps. The first was to screen the individual measures by NPV -measures having a positive NPV were retained for additional analysis. The second was to combine the measures to identify interactive effects in order to avoid double counting the efficiency potential and to deselect measures that reduced the NPV of selected bundles for individual building types. Third, the measure bundles and applicable individual measures were then evaluated for each residential building type to estimate residential sector efficiency potential. Fourth, the residential sector analysis results were extended to the non-residential buildings sector. application:

The following group of 7 measures having an interactive effect were selected for

1. Insulate Building Exterior Side Walls

2. Weatherstrip Elevator Penthouse, Stainway, Doors and Windows

3. Weatherstrip Windows and Doors

4. Install Revolving or Double Door in Vestibule

5. Install Storm Windows

6. Install Zone Valves on Each Radiator and Install Central Thermostats with 'On TimeCounter' in Each Apartment

7. Install Heat Recovery Vent System in Basements

Depending upon the building type, a subset of these items was selected based upon their combined performance. The following seven measures which did not exhibit interactive effects were also selected for application depending on their performance.

1. Install Heat Reflectors Behind Each Radiator or Heater

2. Remove Draperies from Radiator

3. Install Low-Flow Shower Heads

4. Install Flow Restrictors on Faucets

5. Insulate Hot Water Pipes in Unconditioned Spaces

6. Install Hot Water Flow Meters

7. Install Waste Water Heat Recovery Heat Exchanger 


\subsubsection{Baseline Efficiency Assessment}

This section first presents the efficiency assessment using the base economic assumptions and Level 3 fuel prices for the residential and non-residential buildings sectors.

\subsubsection{Residential Sector Baseline Efficiency}

Table 3.4 provides the cost-effective space and water heat efficiency resource by residential sector building and fuel type for 1993 using the base economic assumptions and the Level 3 fuel prices.

The 147,381 GJ of cost-effective savings represents a $42 \%$ reduction in current residential sector energy consumption. This ranges from $3.33 \%$ to $43.43 \%$ of current use for building groups 1,6 and 7 , and $32.7 \%$ to $52.13 \%$ of current use for building groups 2 through 5 . Residential district heating energy use can be cost-effectively reduced by about $46 \%$, which represents over $78.8 \%$ of all of the cost-effective savings. Residential natural gas consumption can be reduced by almost $32 \%$, accounting for almost $15 \%$ of the efficiency potential and coal consumption can be reduced by about $32 \%$, which represents about $6 \%$ of the efficiency potential. Residential electricity use can be cost-effectively reduced by $3 \%$, although this represents only $.03 \%$ of total cost effective savings.

Table 3.5 provides the economic analysis of the residential sector efficiency resource presented in Table 3.4.

The residential sector cost-effective efficiency resource of 147,381 GJ annually, is expected to cost about 131.8 Million SK and have a net present value of 198.3 Million SK. The cost of conserved energy (the annualized cost divided by the annual energy use reduction) works out to an average of $136 \mathrm{SK} / \mathrm{GJ}$ for all fuels. While high rise apartment buildings (building types 2-5) supplied by district heat account for about $77.8 \%$ of residential sector heat and hot water energy consumption, they account for over $80 \%$ of the cost-effective efficiency resource. This 135 SK/GJ estimated cost of this resource appears to be very cost-effective when compared to the current price of 210 SK/GJ for district heat. 
Table 3.4 - Residential Sector Cost-Effective Space and Water Heat Efficiency Resource by Building, Fuel and Equipment Type Using Base Assumptions and 1993 Fuel Prices

\begin{tabular}{|c|c|c|c|c|c|c|c|}
\hline Bldg. & Fuel & Baseline & Tercentof & $\begin{array}{l}\text { Cost } \\
\text { Effective } \\
\text { savings } \\
\text { potential }\end{array}$ & $\begin{array}{c}\text { Effestlve } \\
\text { savings as } \\
\text { percent of }\end{array}$ & $\begin{array}{l}\text { Percent ol } \\
\text { Eotalcostlve } \\
\text { Savings }\end{array}$ & $\begin{array}{l}\text { Evelized } \\
\text { Energy } \\
\text { cost } \\
\text { (SKGG) }\end{array}$ \\
\hline 1 & On-Site Gas & 13330 & $3.82 \%$ & 5789 & 43.43 & $3.93 \%$ & 100.61 \\
\hline $\bar{T}$ & On-Site Coal & 0 & $0.00 \%$ & 0 & $0.00 \%$ & $0.00 \%$ & \\
\hline 1 & Electricity & 0 & $0.00 \%$ & 0 & $0.00 \%$ & $0.00 \%$ & \\
\hline 1 & District Heat & 0 & $0.00 \%$ & 0 & $0.00 \%$ & $0.00 \%$ & \\
\hline 1 & Total & 13330 & $382 \%$ & 5789 & $43.43 \%$ & $393 \%$ & 100.61 \\
\hline 2 & On-Site Gas & 7260 & $2.19 \%$ & 2553 & $33.51 \%$ & $1.73 \%$ & 81.70 \\
\hline 2 & On-Site Coal & 659 & $0.19 \%$ & 216 & $32.78 \%$ & $0.15 \%$ & 76.83 \\
\hline 2 & Electricity & 0 & $0.00 \%$ & 0 & $0.00 \%$ & o| & \\
\hline 2 & District Heat & 69819 & $20.02 \%$ & 24034 & $34.42 \%$ & $16.31 \%$ & 132.75 \\
\hline 2 & Total & 78098 & $23.40 \%$ & 26803 & $3432 \%$ & $18.19 \%$ & 12744 \\
\hline 3 & On-Site Gas & 0 & $0.00 \%$ & 0 & $0.00 \%$ & $0.00 \%$ & \\
\hline 3 & On-Site Coal & 0 & $0.00 \%$ & $\overline{0}$ & $0.00 \%$ & $0.00 \%$ & \\
\hline 3 & Electricity & 0 & $0.00 \%$ & 0 & $0.00 \%$ & $0.00 \%$ & \\
\hline 3 & District Heat & 98405 & $28.22 \%$ & 49150 & $49.95 \%$ & $33.35 \%$ & 155.97 \\
\hline 3 & Total & 98405 & $28.22 \%$ & 49150 & $4995 \%$ & 3355 & 15597 \\
\hline 4 & On-Site Gas & 0 & $0.00 \%$ & 0 & $0.00 \%$ & $0.00 \%$ & \\
\hline 4 & On-Site Coal & 0 & $0.00 \%$ & 0 & $0.00 \%$ & $0.00 \%$ & \\
\hline 4 & Electricity & 0 & $0.00 \%$ & 0 & $0.00 \%$ & $0.00 \%$ & \\
\hline 4 & District Heat & 23618 & $6.77 \%$ & 12146 & $51.43 \%$ & $8.24 \%$ & 132.95 \\
\hline 4 & Total & 23618 & $6 \%$ & 12146 & $5143 \%$ & $824 \%$ & 13295 \\
\hline 5 & On-Site Gas & o & $0.00 \%$ & 0 & $0.00 \%$ & $0.00 \%$ & \\
\hline 5 & On-Site Coal & 0 & $0.00 \%$ & 0 & $0.00 \%$ & $0.00 \%$ & \\
\hline 5 & Electricity & 0 & $0.00 \%$ & 0 & $0.00 \%$ & $0.00 \%$ & \\
\hline 5 & District Heat & 59191 & $16.97 \%$ & 30857 & $52.13 \%$ & $20.94 \%$ & 140.29 \\
\hline 5 & Total & 59191 & $1697 \%$ & 30857 & $5213 \%$ & $2094 \%$ & $140 \% 29$ \\
\hline 6 & On-Site Gas & 15420 & $4.42 \%$ & 3392 & $22.00 \%$ & $2.30 \%$ & 172.17 \\
\hline 6 & On-Site Coal & 400 & $0.11 \%$ & 108 & $27.06 \%$ & $0.07 \%$ & 175.30 \\
\hline 6 & Electricity & 0 & $0.00 \%$ & 0 & $0.00 \%$ & $0.00 \%$ & \\
\hline 6 & District Heat & 0 & $0.00 \%$ & 0 & $0.00 \%$ & $0.00 \%$ & \\
\hline 6 & Total & 55820 & $454 \%$ & 3500 & $2213 \%$ & $238 \%$ & 17227 \\
\hline 7 & On-Site Gas & 30580 & $8.77 \%$ & 9895 & $32.36 \%$ & $6.71 \%$ & 112.08 \\
\hline .7 & On-Site Coal & 28440 & $8.16 \%$ & $\overline{9198}$ & $32.34 \%$ & $6.24 \%$ & 74.07 \\
\hline 7 & Electricity & 1200 & $0.34 \%$ & 40 & $3.33 \%$ & $0.03 \%$ & 168.28 \\
\hline 7 & District Heat & 0 & $0.00 \%$ & 0 & $0.00 \%$ & $0.00 \%$ & 0 \\
\hline 7 & Tolat & 60220 & $1727 \%$ & 19133 & $317 \%$ & $1298 \%$ & 9393 \\
\hline All & On-Site Gas & 66950 & $19.20 \%$ & 21630 & $32.31 \%$ & $14.68 \%$ & 114.85 \\
\hline All & On-Site Coal & 29599 & $8.46 \%$ & 9522 & $32.28 \%$ & $6.46 \%$ & 75.29 \\
\hline All & Electricity & 1200 & $0.34 \%$ & 40 & $3.33 \%$ & $0.03 \%$ & 168.28 \\
\hline All & District Heat & 251033 & $71.99 \%$ & 116187 & $46.28 \%$ & $78.83 \%$ & 144.60 \\
\hline Ails & Total & 348682 & $100.00 \%$ & 47381 & $4227 \%$ & $700.00 \%$ & 13576 \\
\hline
\end{tabular}


Table 3.5 - Economic Analysis Results of Residential Sector Cost-Effective Energy Efficiency Resource for 1993 Baseline

\begin{tabular}{|c|c|c|}
\hline Füll Price Scenario & Bulliding Groups & District Heating Bulloing \\
\hline Economic Assumptions & Default & Default \\
\hline $\begin{array}{l}\text { Annual Energy Use Reduction } \\
\text { (GJ) }\end{array}$ & 147,381 & 116,187 \\
\hline $\begin{array}{l}\text { Value of Annual } \\
\text { Savings (Million } 1993 \mathrm{SK} \text { ) }\end{array}$ & $\overline{35.6}$ & $\overline{31.4}$ \\
\hline $\begin{array}{l}\text { Present Value of Energy } \\
\text { Savings (Million } 1993 \mathrm{SK} \text { ) }\end{array}$ & 529.1 & 480.2 \\
\hline $\begin{array}{l}\text { Total Installed } \\
\text { Cost (Million } 1993 \mathrm{SK} \text { ) }\end{array}$ & 131.8 & 114.2 \\
\hline $\begin{array}{l}\text { PV of Installed } \\
\text { Cost (Million } 1993 \text { SK) }\end{array}$ & $\overline{198.3}$ & 166.5 \\
\hline $\begin{array}{r}\text { Simple Payback } \\
\text { Period (Years) }\end{array}$ & 4 & $\overline{4}$ \\
\hline $\begin{array}{l}\text { Net Present } \\
\text { Value (Million } 1993 \mathrm{SK} \text { ) }\end{array}$ & 330.8 & 313.7 \\
\hline $\begin{array}{l}\text { Annualized Cost } \\
\text { (Million } 1993 \mathrm{SK} / \text { Year) }\end{array}$ & 20.0 & 16.8 \\
\hline $\begin{array}{l}\text { Cost of Conserved } \\
\text { Energy (1993 SK/GJ) }\end{array}$ & 135.8 & 144.6 \\
\hline
\end{tabular}

\subsubsection{Non-Residential Sector Baseline Efficiency}

The non-residential, cost-effective efficiency resource was estimated by applying the percentage of cost-effective energy efficiency in residential buildings to the space and water heating energy use in the non-residential building sector. The estimated non-residential efficiency resource for 1993 using the base economic values and medium fuel prices is shown in Table 3.6.

Table 3.6 Estimated Non-Residential Space and Water Heat Efficiency Potential by Fuel and Heating System Type (GJ), 1993

\begin{tabular}{|c|c|c|c|c|c|}
\hline Gas & onsite: & $\begin{array}{l}\text { Onsite } \\
\text { Electic }\end{array}$ & Gas & District & TOTAL \\
\hline 15 & 0 & 84 & 1061 & 36822 & 40774 \\
\hline
\end{tabular}

Keeping in mind that this is a very rough estimate, the cost-effective efficiency potential in the nonresidential amounts to 40,774 GJ annually. This represents about a $37 \%$ reduction in nonresidential energy consumption and over $90 \%$ of this resource is supplied by district heat. 


\subsubsection{Sensitivity Analysis}

The cost effectiveness of the energy savings and the total energy saving potential are a function of fuel prices, the installed cost of the energy efficiency equipment and the energy savings actually achieved. The sensitivity of levelized energy cost to those input parameters is discussed in this subsection.

\subsubsection{Installed Cost of Equipment}

The purchase and installation cost of the energy saving material and equipment was determined by market research in the Slovak Republic, in other European countries and in the UGA. While the prices in Slovakia are expected to change in some instances, they will not change dramatically. The cost of such equipment in Slovakia is already within the price ranges found in Western countries. Cost of installation can be expected to increase with the time, due to the general growth of wages. However, this can be predicted and taken into account in the period between the study and the actual implementation of the project. Therefore, it will not be considered in the sensitivity analysis.

\subsubsection{Fuel Price}

The cost of fuel can affect the potential energy savings and also the cost of saved energy. A lower fuel price will cause some ECO's to became economically ineffective due to a lower value of energy savings and unchanged installation cost. Thus, ECO's with low value index will be eliminated and the cost effective saving potential will be reduced. The levelized cost of saved energy will not be affected much, since the installation cost of ECO's will also be reduced.

The sensitivity of the energy saving potential and the cost of energy saved in the residential sector were analyzed for all four levels of fuel prices presented in Table 3.3. Level 1 represents the current energy prices, Levels 2 and 3 represent an optimistic estimate of moderate fuel price increases while Level 4 represents a pessimistic scenario of fuel prices development. The selection of fuel price levels is not intended to be an accurate estimate for the price of each fuel. Instead, a wide range of fuel price development scenarios was selected to analyze the relation between the expected energy saving potential and the fuel price. The impact of fuel prices on the levelized cost of heat and on the energy saving potential in the town of Handlova is presented in Table 3.7 . 
Table 3.7 - Sensitivity of the Energy Saving Potential and the Cost of Delivered Heat to Fuel Prices

\begin{tabular}{|c|c|c|c|c|}
\hline Fuel Price Level & 1 & 2 & 3 & 4 \\
\hline \multicolumn{5}{|c|}{ All Fuels } \\
\hline $\begin{array}{l}\text { Saving Potential } \\
\text { [GJ/Year] }\end{array}$ & $\begin{array}{l}125,168 \\
35.9 \%\end{array}$ & $\begin{array}{l}140,825 \\
40.4 \%\end{array}$ & $\begin{array}{l}147,381 \\
42.2 \%\end{array}$ & $\begin{array}{l}154,238 \\
44.2 \%\end{array}$ \\
\hline $\begin{array}{l}\text { Levelized Cost } \\
\text { [SK/GJ] }\end{array}$ & 132.47 & 133.79 & 135.76 & 140.14 \\
\hline \multicolumn{5}{|c|}{ District Heat } \\
\hline $\begin{array}{l}\text { Saving Potential } \\
\text { [GJ/Year] }\end{array}$ & $\begin{array}{l}112,556 \\
44.8 \%\end{array}$ & $\begin{array}{l}112,556 \\
44.8 \%\end{array}$ & $\begin{array}{l}116,187 \\
46.3 \%\end{array}$ & $\begin{array}{l}117,416 \\
46.8 \%\end{array}$ \\
\hline $\begin{array}{l}\text { Levelized Cost } \\
\text { [SK/GJ] }\end{array}$ & 135.85 & 141.87 & 144.60 & 149.66 \\
\hline
\end{tabular}

The data in Table 3.7 indicates that the energy saving potential for Level 1 is lower than Level 4 by approximately $8 \%$ for all fuel groups and by approximately $2 \%$ for the district heating group only. The variation of the levelized energy cost for all fuel groups is within $5 \%$ and for district heat only within $9 \%$ of the highest value. This comparison indicates that the fuel price will have only a small impact on the cost effective potential energy savings and on the cost of the energy saved.

\subsubsection{Actual Energy Savings Achieved}

The energy saving potential in the residential building stock was calculated using methods recommended by the American Society of Heating, Refrigerating and Air Conditioning Engineers (ASHRAE). However, inherent to this process is that many assumptions have to be made based on experience and results from previous studies and demonstrations. A certain level of inaccuracy has to be recognized. Another issue is that implementation of the energy saving technologies depends on the quality of workmanship, materials and equipment used, and other factors which are difficult to predict.

The reason for analyzing the sensitivity of the economically effective energy saving potential and the levelized cost of saved energy to the savings actually achieved is not to raise skepticism about the calculated results, but to make an assessment of consequences due to the above mentioned factors. Lower-than-expected energy savings will increase the levelized cost of saved energy and reduce the energy saving potential.

For the purpose of this analysis, the calculated savings for each ECO was reduced to $50 \%$ of the calculated value which means that only $50 \%$ of calculated savings would be achieved. Fuel Case 3 was selected for the calculation. The results are presented in Table 3.8. 
Table 3.8 - Sensitivity of the Energy Saving Potential and the Cost of Delivered Heat to Actual Energy Savings Achieved

\begin{tabular}{|c|c|c|c|}
\hline & $\begin{array}{l}\text { Levelized } \\
\text { Energy Cost } \\
\text { [S/G/GJ] }\end{array}$ & $\begin{array}{l}\text { Cost Effective } \\
\text { Saving Potential } \\
\text { [G/Year] }\end{array}$ & $\begin{array}{l}\text { Effective saving } \\
\text { as \% of Total } \\
\text { Ose }\end{array}$ \\
\hline All fuels $100 \%$ saving & 135.76 & 147,381 & 42.27 \\
\hline All fuels $50 \%$ saving & 267.75 & 58,940 & 16.90 \\
\hline District Heat $100 \%$ saving & 144.60 & 116,187 & 46.28 \\
\hline District Heat $50 \%$ saving & 274.60 & 54,060 & 21.54 \\
\hline
\end{tabular}

In the unlikely scenario where only $50 \%$ of expected energy savings would be actually achieved, the cost effective saving potential for all the fuel groups would be reduced to 58,940 GJ/year, or by $60 \%$. In the district heating system, the saving potential would be lowered by approximately $53 \%$. The levelized energy cost for all fuel groups and for the district heating system only would increase to $267.75 \mathrm{SK} / \mathrm{GJ}$ and $274.60 \mathrm{SK} / \mathrm{GJ}$, respectively. The results of the analysis of the three supply side alternatives shows that the cost of delivered thermal energy would be in a range from $180 \mathrm{SK} / \mathrm{GJ}$ to $350 \mathrm{SK} / \mathrm{GJ}$, depending on selected alternatives, cost of fuel and economic environment. The cost of energy saved (274.60 SK/GJ) under this scenario is only slightly higher than the cost of thermal energy delivered by the district heating system assumed for this calculation, as previously shown in Table 3.3 (270 SK/GJ).

\subsubsection{Summary of Sensitivity Analysis}

The sensitivity analysis shows that:

the Levelized Cost (LC) of the energy saved by implementing the energy conservation measures evaluated in this study is only moderately influenced by fuel prices. The LC variation is less than $6 \%$ for the fuel cost variation of approximately $80 \%$.

- the LC of energy saved will be well within the range of expected cost of energy delivered by the district heating system even in the unlikely case that only $50 \%$ of the calculated energy savings are achieved. This suggests that the economic risk of implementing the recommended ECO's is almost non-existing.

- the energy saving potential is only moderately influenced by the fuel prices within the assumed range. The variation of saving potential is less than $6.5 \%$ for the fuel cost variation of approximately $80 \%$. 
- the energy saving potential is substantially dependent on the actual performance of each ECO. For the analyzed case where only $50 \%$ of calculated savings were assumed, the energy saving potential (as calculated for $100 \%$ savings) was reduced by approximately $60 \%$ for all fuel groups and by $53 \%$ for the district heating system. 